\title{
Integrative taxonomy of five astome ciliates (Ciliophora, Astomatia) isolated from earthworms in Central Europe
}

\author{
Tomáš OBERT ${ }^{1} \&$ Peter VĎAČNÝ $2, *$ \\ ${ }^{1,2}$ Department of Zoology, Comenius University in Bratislava, 84215 Bratislava, Slovakia. \\ *Corresponding author: peter.vdacny@uniba.sk \\ ${ }^{1}$ Email: tomasobert.obert@gmail.com \\ ${ }^{1}$ urn:lsid:zoobank.org:author:DBA6C599-9060-46FE-93CD-FE157754186B \\ ${ }^{2}$ urn:1sid:zoobank.org:author:47A28E80-E04F-40C4-93A3-F7F685C9533A
}

\begin{abstract}
Four earthworm species, the endogeic Octolasion tyrtaeum (Savigny, 1826), the anecic Lumbricus terrestris Linnaeus, 1758 as well as the epigeic Eisenia fetida (Savigny, 1826) and Dendrobaena veneta (Rosa, 1886), were examined for the presence of astome ciliates. Based on the integrative taxonomic approach, five ciliate species were recognized in their gastrointestinal tracts: Metaradiophrya lumbrici (Dujardin, 1841), M. varians (de Puytorac, 1954), Anoplophrya lumbrici (Schrank, 1803), A. vulgaris de Puytorac, 1954 and A. nodulata (Dujardin, 1841). Their distinctness was assessed using the multivariate morphometric approach and molecular phylogenetic analyses. Although the two species of Metaradiophrya Jankowski, 2007 on the one hand and the two former species of Anoplophrya Stein, 1860 on the other, were not distinctly separated by the multivariate morphometric analyses, they were clearly delimited by the $18 \mathrm{~S}$ rRNA gene sequences. Species within each genus also differed by their hosts, $M$. lumbrici and $A$. lumbrici occurred only in anecic earthworms while $M$. varians and $A$. vulgaris occured exclusively in epigeic earthworms. Only a single species, A. nodulata, was detected in endogeic earthworms. It was morphologically distinct from and did not cluster with the two other species of Anoplophrya but was nested within the paraphyletic assemblage containing other astomes from endogeic earthworms. This indicates that the evolution of endosymbiotic ciliates from earthworms has very likely proceeded through a specialization to various ecological groups of their host organisms.
\end{abstract}

Keywords. 18S rRNA gene, Anoplophrya, Lumbricidae, Metaradiophrya, morphometry.

Obert T. \& Vd'ačný P. 2019. Integrative taxonomy of five astome ciliates (Ciliophora, Astomatia) isolated from earthworms in Central Europe. European Journal of Taxonomy 559: 1-37. https://doi.org/10.5852/ejt.2019.559

\section{Introduction}

The subclass Astomatia Schewiakoff, 1896 unites ciliates lacking cytostome, cytopharynx and all oral ciliary structures, such as paroral membrane or adoral organelles. Based on the ultrastructural and molecular data, mouthless (astome) ciliates are classified within the species-rich and highly morphologically as well as ecologically diverse class Oligohymenophorea de Puytorac et al., 1974 
(Lynn 2008; Fokam et al. 2011; Rataj \& Vd’ačný 2018, 2019). Astomes are endosymbionts typically inhabiting the gastrointestinal tract of a huge variety of animals, ranging from turbellarians (e.g., von Siebold 1839; Schultze 1851; Kijenskij 1926; de Puytorac 1957, 1963; Sikora 1963; Corliss et al. 1965), mollusks (Lom 1959) and annelids (for reviews, see Cépède 1910 and de Puytorac 1954, 1969, 1972) to newts and frogs (e.g., Maupas 1879; Bush 1933, 1934; Kay 1942; McAllister et al. 1993; McAllister \& Trauth 1996). The majority of astome ciliates has been, however, discovered in annelids including polychaetes (de Puytorac 1954; de Puytorac \& Schrével 1965; Sauvadet et al. 2017), leeches and, especially, in a variety of aquatic and terrestrial oligochaetes (e.g., Cépède 1910; Rossolimo 1926a, 1926b; Heidenreich 1935; de Puytorac 1954, 1969, 1972; Ngassam 1983; Ngassam et al. 1998; Fokam et al. 2008, 2015, 2016).

The gastrointestinal tract of earthworms from the oligochaete family Lumbricidae RafinesqueSchmaltz, 1815 is inhabited by astomes belonging to only three genera: Metaradiophrya Jankowski, 2007, Anoplophrya Stein, 1860 and Maupasella Cépède, 1910 (Heidenreich 1935; Lom 1961; de Puytorac 1972). Each genus has dozens of species and some of them have a complex taxonomic history (see, Heidenreich 1935; Beers 1938; Williams 1942; Lom 1961; de Puytorac 1972). Most taxonomic problems have arisen from the paucity of morphological differential features as well as from the lack of information on intraspecies variability and host range. Host species very likely constitute clearly isolated ecological niches that might permit speciation of symbiotic ciliates (Irwin \& Lynn 2015; Irwin et al. 2017; Vd'ačný 2018; Vd’ačný et al. 2018, 2019), although no distinct apomorphic morphological features might be recognizable between astomes originated from different hosts. In this case, molecular data could independently prove the species identity and could also help to statistically delimit species boundaries (Abraham et al. 2019). Unfortunately, except for the study of Affa'a et al. (2004), molecular data are completely missing from astome ciliates isolated from lumbricid earthworms, although there are some reports from earthworms of the families Megascolecidae Rosa, 1891 and Glossoscolecidae Michaelsen, 1900 (Fokam et al. 2011).

Therefore, in the present study, we apply an integrative approach to study astome ciliates inhabiting the gastrointestinal tract of some lumbricid earthworms originated from Slovakia, Central Europe. Our main goals are set as follows:

1. to study the diversity and phylogeny of astome ciliates inhabiting the gastrointestinal tract of lumbricid earthworms.

2. to test the host specificity of endosymbiotic ciliates to certain ecological groups of earthworms, using $18 \mathrm{~S}$ rRNA gene sequences.

3. to assess the morphological and genetic variability of astome ciliates isolated from lumbricid earthworms.

\section{Material and methods}

\section{Material collection and processing}

Earthworms from the family Lumbricidae were sampled at seven localities in the capital of Bratislava and in its vicinity, western Slovakia, Central Europe (Fig. 1; Table 1). Collected lumbricids were transferred together with in situ substrates to the laboratory at the Department of Zoology, Comenius University in Bratislava. Their identification was based on morphological characters and followed the monograph of Pižl (2002). In total, four earthworm species were determined: Lumbricus terrestris Linnaeus, 1758, Eisenia fetida (Savigny, 1826), Dendrobaena veneta (Rossa, 1886) and Octolasion tyrtaeum (Savigny, 1826). After identification, earthworms were euthanized in formalin (37\%) vapors, their guts were dissected and their contents were extracted with a micropipette and observed under an optical microscope Leica DM2500. Ciliate endosymbionts were manually isolated from the gut content 
with the aid of Pasteur micropipettes adjusted as described by Foissner (2014). Living ciliates were investigated at low $\left(50-400^{\prime}\right)$ and high $\left(1000^{\prime}\right.$, oil immersion) magnifications, using bright field and differential interference contrast optics (Foissner 2014). Images were captured by a Canon EOS 70D camera. Ciliates were measured from images, using the calibrated software ImageJ ver. 1.49 (Schneider et al. 2012).

\section{Multivariate taxonomic methods}

A multivariate approach was used to investigate the morphometric variation and distinctness of four astome species isolated from the gastrointestinal tract of earthworms. Altogether, 16 quantitative features, a single qualitative character and two derived ratios were scored on 33 specimens. The libraries NumPy (Oliphant 2015) and Pandas (McKinney 2010) were utilized to load and process the morphometric matrix in Python ver. 3.6.6. The similarity of specimens was measured by Gower's coefficient $G O W$ (Gower 1971):

$$
\operatorname{GOW}_{i j}=\frac{\sum_{k=1}^{n} w_{i j k} s_{i j k}}{\sum_{k=1}^{n} w_{i j k}}
$$
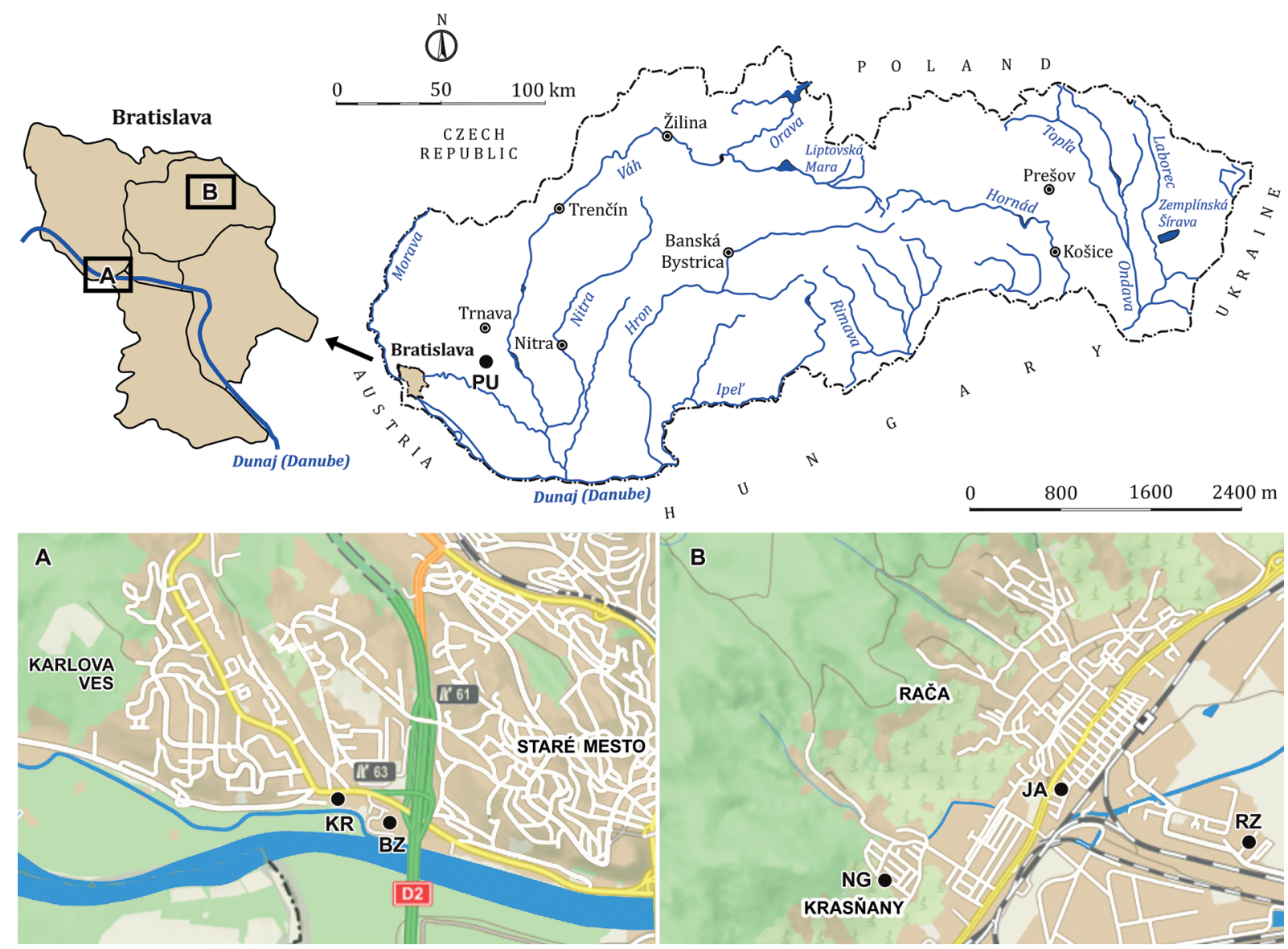

Fig. 1. Map of Slovakia showing the localization of six collection sites (marked by black dots). A schematized outline of Bratislava City is depicted left of the map of Slovakia. Rectangles A and B indicate the two Bratislava study areas, whose details are shown in panels (A) and (B) under the map of Slovakia. For locality codes and further details, see Table 1. 
Table 1. Characterization of collection sites of earthworm species examined for the presence of astome ciliates. For localization of localities, see Fig. 1.

\begin{tabular}{|c|c|c|c|c|}
\hline Collection date & Collection site & $\begin{array}{c}\text { Locality } \\
\text { code }\end{array}$ & GPS coordinates & Host species \\
\hline 6 Jun. 2017 & $\begin{array}{l}\text { Agricultural, brown soil } \\
\text { from a garden, Śúrska ulica } \\
\text { street, Rendez, Bratislava }\end{array}$ & $\mathrm{RZ}$ & $\begin{array}{l}48^{\circ} 11^{\prime} 57.6^{\prime \prime} \mathrm{N} \\
17^{\circ} 10^{\prime} 25.0^{\prime \prime} \mathrm{E}\end{array}$ & Lumbricus terrestris Linnaeus, 1758 \\
\hline 3 Oct. 2017 & $\begin{array}{l}\text { Floodplain soil from } \\
\text { a riparian, willow-poplar } \\
\text { forest near the Karlova Ves } \\
\text { branch of the Danube river, } \\
\text { Bratislava }\end{array}$ & $\mathrm{KR}$ & $\begin{array}{l}48^{\circ} 08^{\prime} 47.5^{\prime \prime} \mathrm{N} \\
17^{\circ} 04^{\prime} 08.0^{\prime \prime} \mathrm{E}\end{array}$ & Lumbricus terrestris Linnaeus, 1758 \\
\hline 19 May 2018 & $\begin{array}{l}\text { Decomposing plant } \\
\text { material from a compost } \\
\text { heap in the Botanical } \\
\text { Garden, Karlova Ves, } \\
\text { Bratislava }\end{array}$ & $\mathrm{BZ}$ & $\begin{array}{l}48^{\circ} 08^{\prime} 43.5^{\prime \prime} \mathrm{N} \\
17^{\circ} 04^{\prime} 21.1^{\prime \prime} \mathrm{E}\end{array}$ & Eisenia fetida (Savigny, 1826) \\
\hline 28 Jun. 2018 & $\begin{array}{l}\text { Decomposing plant } \\
\text { material and humous soil } \\
\text { from a garden compost } \\
\text { heap, Jakubská ulica street, } \\
\text { Rača, Bratislava }\end{array}$ & JA-1 & $\begin{array}{l}48^{\circ} 12^{\prime} 10.9^{\prime \prime} \mathrm{N} \\
17^{\circ} 09^{\prime} 05.7^{\prime \prime} \mathrm{E}\end{array}$ & Eisenia fetida (Savigny, 1826) \\
\hline 28 Jun. 2018 & $\begin{array}{l}\text { Loamy soil with fallen } \\
\text { needles in the surroundings } \\
\text { of a garden wall, Jakubská } \\
\text { ulica street, Rača, } \\
\text { Bratislava }\end{array}$ & JA-2 & $\begin{array}{l}48^{\circ} 12^{\prime} 12.2^{\prime \prime} \mathrm{N} \\
17^{\circ} 09^{\prime} 03.1^{\prime \prime} \mathrm{E}\end{array}$ & Lumbricus terrestris Linnaeus, 1758 \\
\hline 30 Jun. 2018 & $\begin{array}{l}\text { Humous soil with high } \\
\text { content of decomposing } \\
\text { plant material from } \\
\text { a garden at the foothill of } \\
\text { the Malé Karpaty Mts., Na } \\
\text { Grunte street, Krasňany, } \\
\text { Bratislava }\end{array}$ & NG & $\begin{array}{l}48^{\circ} 11^{\prime} 44.4^{\prime \prime} \mathrm{N} \\
17^{\circ} 07^{\prime} 47.5^{\prime \prime} \mathrm{E}\end{array}$ & Dendrobaena veneta (Rosa, 1886) \\
\hline 2 Jul. 2018 & $\begin{array}{l}\text { Upper } 50 \mathrm{~cm} \text { turf layer in } \\
\text { the riparian zone of the } \\
\text { Rašelinisko pond in the } \\
\text { vicinity of the Pusté Úl'any } \\
\text { village, Galanta district }\end{array}$ & PU & $\begin{array}{l}48^{\circ} 13^{\prime} 21.9^{\prime \prime} \mathrm{N} \\
17^{\circ} 34^{\prime} 49.9^{\prime \prime} \mathrm{E}\end{array}$ & Octolasion tyrtaeum (Savigny, 1826) \\
\hline
\end{tabular}

where $i$ and $j$ are specimens, $s_{i j k}$ is the contribution provided by the $k$-th variable and $w_{i j k}$ is 1 or 0 depending upon whether or not the comparison is valid for the $k$-th variable. Values of $s_{i j k}$ for variables measured at interval and ratio scales are defined as follows:

$$
s_{i j k}=1-\frac{\left|x_{i k}-x_{j k}\right|}{R_{k}}
$$

where $x_{i k}$ is the value of the $k$-th variable on the specimen $i, x_{j k}$ is the value of the $k$-th variable on the specimen $j$ and $R_{k}$ is the range of values for the $k$-th variable. Values of $s_{i j k}$ for binary qualitative variables are 1 , if $i$ and $j$ both have the attribute $k$ present or 0 otherwise. The weight $w_{i j k}$ causes negative matches to be ignored. The function for computation of Gower's coefficient was obtained from https://github.com/scikit-learn/scikit-learn/pull/9555. 
OBERT T. \& VĎAČNÝ P., Morphology and phylogeny of five astome ciliates

The similarity of specimens, as measured by Gower's index, was assessed by metric multi-dimensional scaling implemented in the scikit-learn package (Pedregosa et al. 2011). The SMACOF algorithm was run with 250 initializations, each run had 20000 iterations and $\varepsilon$ was set to $10^{-8}$ to declare convergence. Plotting of the ordination diagram was done with the Matplotlib module (Hunter 2007).

\section{Molecular methods}

Single cells were picked and washed in five drops of Ringer's solution (0.6\%). Thoroughly washed specimens were stored in $180 \mu 1$ of the cell lysis buffer CLD (Promega, Fitchburg, Wisconsin, USA) at $6^{\circ} \mathrm{C}$. Genomic DNA from single cells was extracted with the ReliaPrep ${ }^{\mathrm{TM}}$ Blood gDNA Miniprep System (Promega, Fitchburg, Wisconsin, USA). The 18S rRNA gene was amplified with the universal eukaryotic primers Euk A (5'-AAC CTG GTT GAT CCT GCC AGT-3') and Euk B (5'-TGA TCC TTC TGC AGG TTC AC-3') (Medlin et al. 1988). Individual polymerase chain reactions (PCR) included $5 \mu \mathrm{l}$ of the extracted template DNA, $0.4 \mu \mathrm{l}$ of the forward and reverse primers each $(10 \mathrm{pmol} / \mu \mathrm{l})$ and $10 \mu 1$ of the GoTaq ${ }^{\circledR}$ Long PCR Master Mix (Promega, Fitchburg, Wisconsin, USA). The final volume was adjusted to $20 \mu \mathrm{l}$ with deionized distilled water. PCR conditions were as follows: initial hot start denaturation at $95^{\circ} \mathrm{C}$ for $15 \mathrm{~min}, 30$ identical amplification cycles (denaturing at $95^{\circ} \mathrm{C}$ for $45 \mathrm{~s}$, annealing at $55^{\circ} \mathrm{C}$ for $1 \mathrm{~min}$ and extension at $72^{\circ} \mathrm{C}$ for $2.5 \mathrm{~min}$ ) and final extension at $72^{\circ} \mathrm{C}$ for $10 \mathrm{~min}$. The quality of the amplified DNA was checked by electrophoresing a 1\% agarose gel. PCR products were purified using calf intestinal alkaline phosphatase and exonuclease I, E. coli (New England Biolabs ${ }^{\circledR}$ Inc.) and sequenced on an ABI 3730 automatic sequencer (Macrogen, Amsterdam, The Netherlands).

\section{Phylogenetic methods}

Newly obtained sequences were examined in Chromas ver. 2.6.6 (Technelysium Pty Ltd.) and highquality sequence fragments were assembled into contigs in BioEdit ver. 7.2.5 (Hall 1999). Two 18S rRNA gene alignments were generated on the GUIDANCE2 server (http://guidance.tau.ac.il/ver2/), with the MAFFT algorithm and 100 bootstrap repeats (Sela et al. 2015). The first alignment (referred as 'general' henceforth) included 73 taxa and served to classify the newly obtained sequences into oligohymenophorean subclasses. Representatives from all subclasses were selected to cover their diversity and sampling basically followed our previous studies (Rataj \& Vd'ačný 2018, 2019). Members from the subclass Peniculia were used to a posteriori root the trees (Fokam et al. 2011). The second alignment (referred as 'detailed' henceforth) contained 34 sequences from the oligohymenophorean subclass Astomatia and two outgroup sequences of Dexiotricha Stokes, 1885 from the subclass Scuticociliatia Small, 1967. Sampling in this dataset mostly followed Fokam et al. (2011) and Rataj \& Vd'ačný $(2018,2019)$ and served to more closely analyze the phylogenetic position of the new astome isolates. To estimate the reliability of alignments, unmasked datasets and datasets masked with a cutoff value of 0.93 were constructed.

The best evolutionary substitution models for all datasets were estimated and selected in jModelTest ver. 2.1.10 under the Akaike Information Criterion (Darriba et al. 2012) on the Cipres portal ver. 3.1 (http://www.phylo.org/) (Miller et al. 2010). Phylogenetic relationships among oligohymenophorean ciliates were reconstructed in the maximum likelihood, Bayesian and neighbor-joining framework under the GTR $+\Gamma+$ I evolutionary model with parameters as estimated in jModelTest. Maximum likelihood analyses were performedin PhyMLver.3.0 with the SPR swapping algorithm and 1000 non-parametric bootstrap replicates on the South of France bioinformatics platform (http://www.atgc-montpellier.fr/phyml/) (Guindon et al. 2010). Bayesian inferences were conducted on the Cipres portal ver. 3.1 in the program MrBayes on XSEDE ver. 3.2.6 (Ronquist et al. 2012). Prior parameters of the GTR $+\Gamma+\mathrm{I}$ evolutionary model were implemented with the 'lset' and 'prset' commands in the MrBayes command block. Two runs, each having four (one cold and three heated) simultaneous Markov chains, were five million generations long. The sampling frequency was set to one hundred and the burn-in fraction was specified as $25 \%$. In addition, the second set of detailed alignments was also analyzed by the neighbor-joining 
algorithm in MEGA X (Kumar et al. 2018). All trees were computed as unrooted and were rooted $a$ posteriori in FigTree ver. 1.2.3 (http://tree.bio.ed.ac.uk/software/figtree/).

Reliability of alternative tree topologies was assessed by the approximately unbiased, weighted Shimodaira-Hasegawa and weighted Kishino-Hasegawa tests (Shimodaira \& Hasegawa 2001; Shimodaira 2002, 2008). Topologically unconstrained and constrained trees were constructed under the GTR $+\Gamma+$ I evolutionary model, using the heuristic search, random sequence addition and the SPR swapping algorithm in the program PAUP* ver. $4.0 \mathrm{~b} 8$ (Swofford 2003). Site-wise log likelihoods were calculated for unconstrained and constrained trees and served to calculate $p$-values for the tree topology tests in the program package CONSEL, using the commands makermt, consel and catpv (Shimodaira \& Hasegawa 2001).

Average evolutionary distances among the five species of astome ciliates isolated from lumbricid earthworms, were calculated from their 18S rRNA gene alignment with the maximum composite likelihood model in MEGA X (Kumar et al. 2018). Standard errors of between group evolutionary distances were estimated with the bootstrap method and 1000 replicates. The rate variation among sites was modeled with a gamma distribution and the differences in the composition bias among sequences were considered in evolutionary comparisons (Tamura \& Kumar 2002).

\section{Abbreviations used in the text}

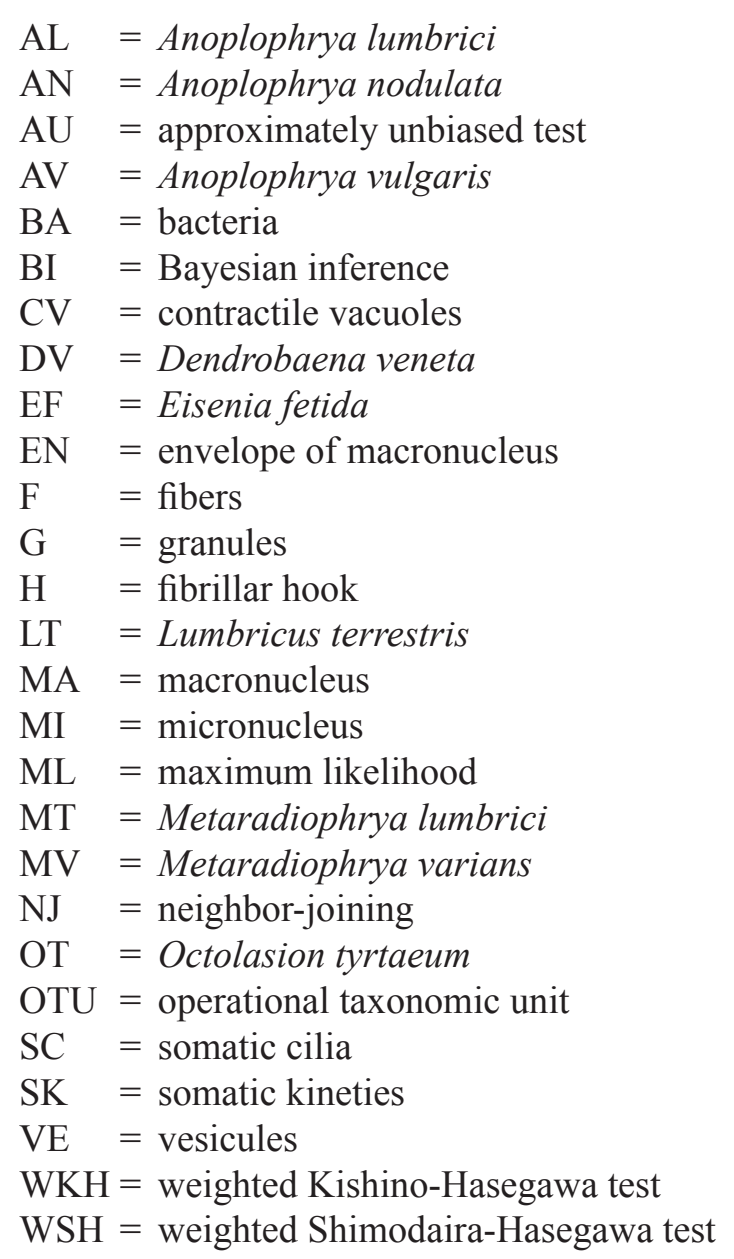


OBERT T. \& VĎAČNÝ P., Morphology and phylogeny of five astome ciliates

Table 2. Occurrence of astome ciliates in earthworm species examined during the course of this study.

\begin{tabular}{|c|c|c|c|c|c|c|}
\hline \multirow[t]{2}{*}{ Collection site $^{\mathrm{a}}$} & \multirow[t]{2}{*}{ Host species } & \multicolumn{5}{|c|}{ Endosymbiont species ${ }^{b}$} \\
\hline & & MT & MV & $\mathbf{A L}$ & $\mathbf{A V}$ & $\mathbf{A N}$ \\
\hline $\mathrm{RZ}$ & Lumbricus terrestris & + & - & + & - & - \\
\hline KR & Lumbricus terrestris & + & - & + & - & - \\
\hline $\mathrm{BZ}$ & Eisenia fetida & - & + & - & + & - \\
\hline JA-1 & Eisenia fetida & - & + & - & + & - \\
\hline JA-2 & Lumbricus terrestris & + & - & + & - & - \\
\hline $\mathrm{NG}$ & Dendrobaena veneta & - & - & - & + & - \\
\hline PU & Octolasion tyrtaeum & - & - & - & - & + \\
\hline
\end{tabular}

\section{Results}

\section{Diversity of astome ciliates in the gastrointestinal tract of lumbricid earthworms}

In total, 300 earthworms were investigated for astome ciliates: 150 specimens of Lumbricus terrestris, 120 individuals of Eisenia fetida, 25 exemplars of Dendrobaena veneta and five specimens of Octolasion tyrtaeum. Five species of endosymbiotic astome ciliates were isolated from their gastrointestinal tract: Metaradiophrya lumbrici, M. varians, Anoplophrya lumbrici, A. vulgaris and A. cf. nodulata (Table 2).

Occurrence and abundance of astome ciliates were highly variable. Immature earthworms typically did not contain any ciliates, only bacterial clumps and sometimes nematodes. About one half of mature earthworms exhibiting a clitellum was inhabited by 10 to 50 ciliates per oligochaete. Sometimes, a mass occurrence of M. lumbrici was recorded in earthworms longer than $15 \mathrm{~cm}$. Endosymbionts were typically found in the middle part of the gastrointestinal tract.

\section{Descriptions of five astome ciliates isolated from lumbricid earthworms}

Phylum Ciliophora Doflein, 1901

Subphylum Intramacronucleata Lynn, 1996

Class Oligohymenophorea de Puytorac et al., 1974

Subclass Astomatia Schewiakoff, 1896

Order Astomatida Schewiakoff, 1896

Family Radiophryidae de Puytorac et al., 1972

Genus Metaradiophrya Jankowski, 2007

Metaradiophrya lumbrici (Dujardin, 1841)

Figs 2, 3, 4, 5

\section{Description}

The body size is about $105-230 \times 55-130 \mu \mathrm{m}$, with an average of $170 \times 100 \mu \mathrm{m}$. The shape is ovate to elliptical with an anterior body end rounded and posterior end broadly rounded to truncate. The cell is distinctly dorsoventrally flattened (Figs 2A, F, 3B, F-M, 4A-B, E-F). On the ventral side, about $10 \mu \mathrm{m}$ away from the anterior body end, there is a conspicuous fibrillar hook composed of two unequally long arms. The longer arm is $25-35 \mu \mathrm{m}$ long, flat and completely situated underneath the cell surface. The shorter arm is $8-13 \mu \mathrm{m}$ long, usually appears slightly more robust at the base and projects from the cell 


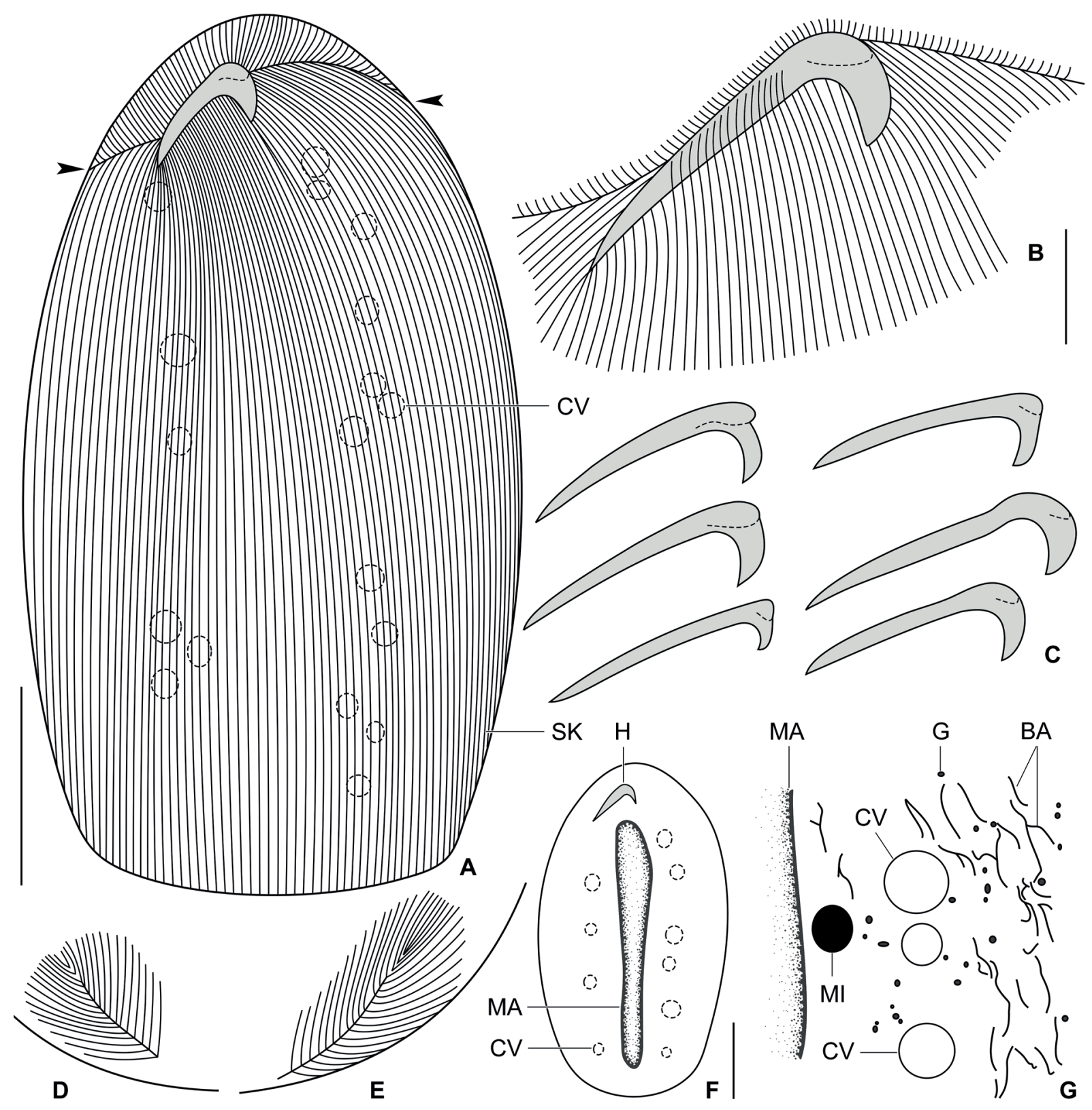

Fig. 2. Metaradiophrya lumbrici (Dujardin, 1841), Slovak specimens in vivo. A. Semi-schematic diagram of the ventral side, showing the fibrillar hook as well as the contractile vacuole and the somatic ciliary pattern. Arrowheads mark the subapical suture extending from the right body margin over the hook towards the left body margin. B. Detail of the anterior body portion, showing the fibrillar hook and its associated fibers. There are on average $6(5-7)$ fibers attached to the upper right side of the longer arm, on average 33 (30-37) fibers to the ventral side of the longer arm and on average 11 (8-13) fibers to the left side of the shorter arm. C. Shape variants of fibrillar hooks. The hook is composed of two unequally long arms: the longer arm is flat and $25-35 \mu \mathrm{m}$ long, while the shorter arm appears slightly more robust at the base and is $8-13 \mu \mathrm{m}$ long. D-E. Lateral somatic kineties form a right and a left subterminal suture in the posterior body region. F. Ventral view, showing the general body organization. G. The cytoplasm contains innumerable granules being ca $0.4 \mu \mathrm{m}$ across and rod-like bacteria being about 3-15 $\mu \mathrm{m}$ long. Scale bars: A, $\mathrm{F}=50 \mu \mathrm{m} ; \mathrm{B}=10 \mu \mathrm{m}$. 

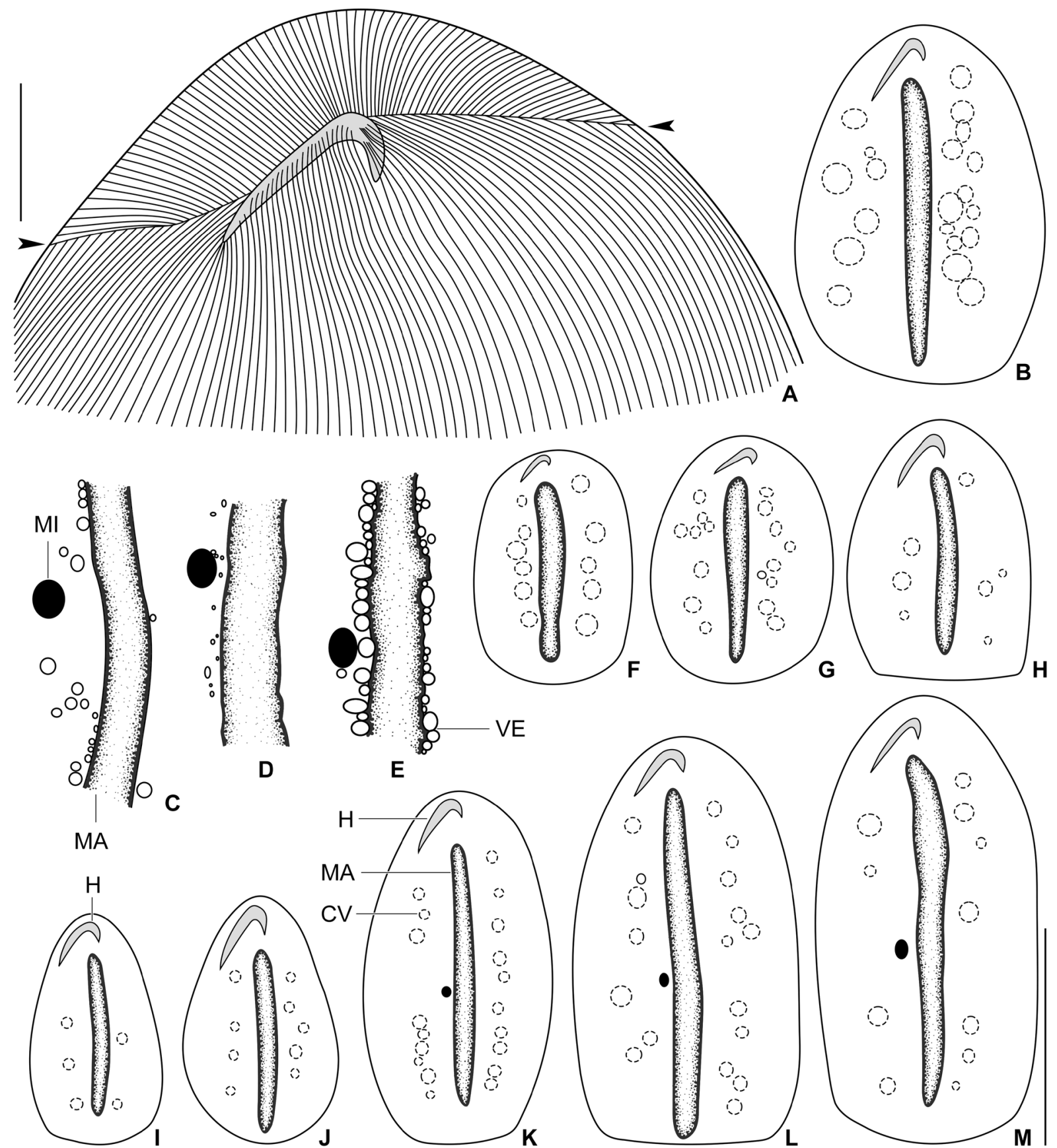

Fig. 3. Metaradiophrya lumbrici (Dujardin, 1841), Slovak specimens in vivo. A. Detail of the anterior body portion, showing the fibrillar hook and its associated fibers. There are on average 6 (5-7) fibers attached to the upper right side of the longer arm, on average 33 (30-37) fibers to the ventral side of the longer arm and on average 11 (8-13) fibers to the left side of the shorter arm. Arrowheads mark the subapical suture extending from the right body margin over the fibrillar hook towards the left body margin. B, F-M. Variability of body shape and size as well as of the contractile vacuole and nuclear apparatus. Drawn to scale. C-E. The macronucleus is rod-like and its surface is smooth or with some indistinct irregularities. However, many small vesicules appear in its vicinity in dying cells. The micronucleus is elliptical and typically situated close to the mid-portion of the macronucleus. Scale bars: $\mathrm{A}=20 \mu \mathrm{m} ; \mathrm{B}, \mathrm{F}-\mathrm{M}=100 \mu \mathrm{m}$. 

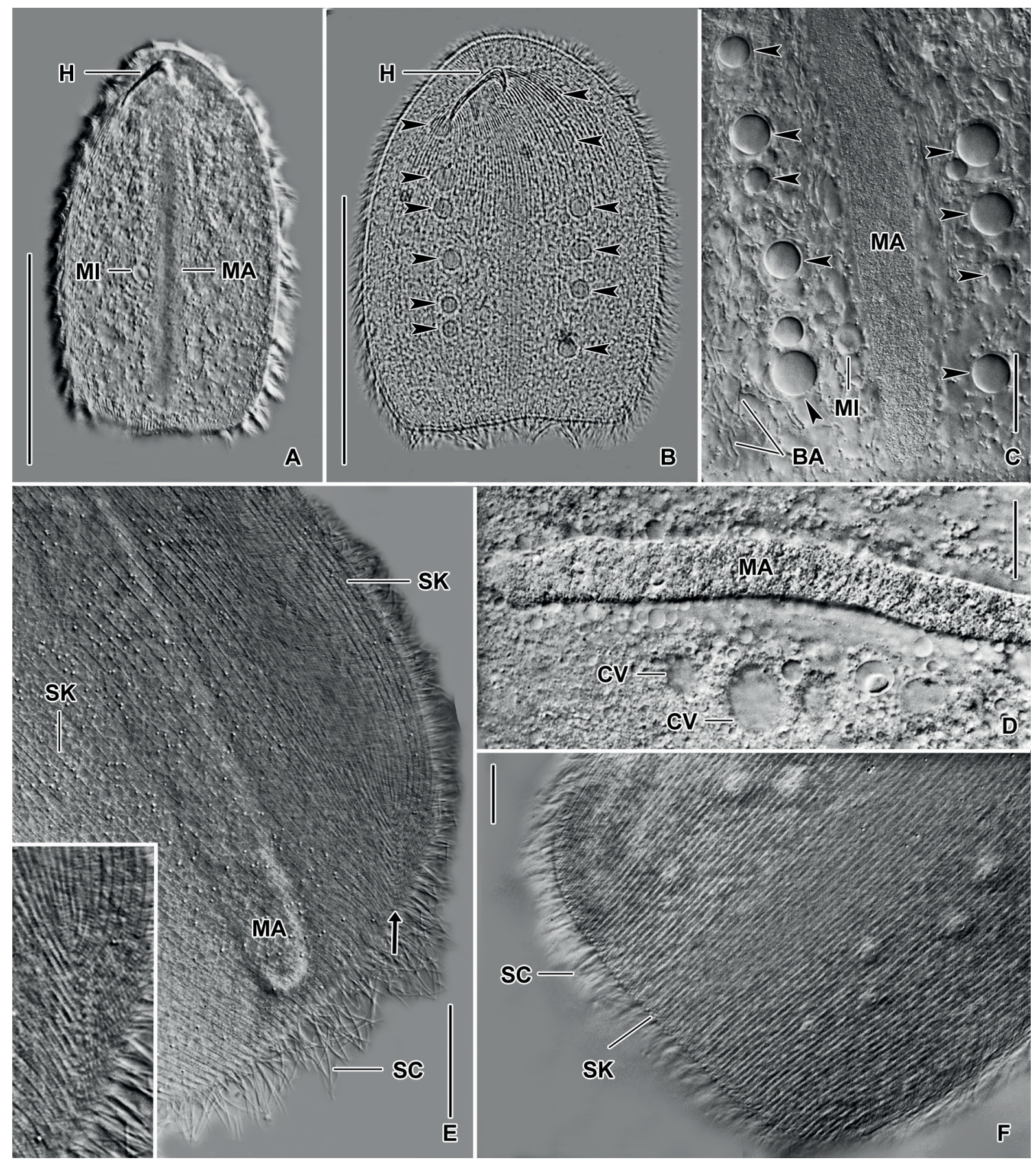

Fig. 4. Metaradiophrya lumbrici (Dujardin, 1841), Slovak specimens in vivo. A-B. Ventral view of representative specimens, showing the typical body shape, localization of the fibrillar hook, the long rod-like macronucleus and two staggered rows of contractile vacuoles (arrowheads). C-D. Detail, showing the long rod-like macronucleus, a single micronucleus, contractile vacuoles and cytoplasmic bacteria. The central region of the micronucleus appears homogenous and brighter than its margin in the differential interference optics and might represent a central nucleolus. E-F. Somatic ciliature is holotrichous and composed of very densely ciliated meridional kineties. In the posterior body region, lateral somatic kineties form a right and a left subterminal suture (arrow in E), whose detail is shown in the left inset. Scale bars: A-B $=100 \mu \mathrm{m} ; \mathrm{C}-\mathrm{D}=10 \mu \mathrm{m} ; \mathrm{E}-\mathrm{F}=20 \mu \mathrm{m}$. 

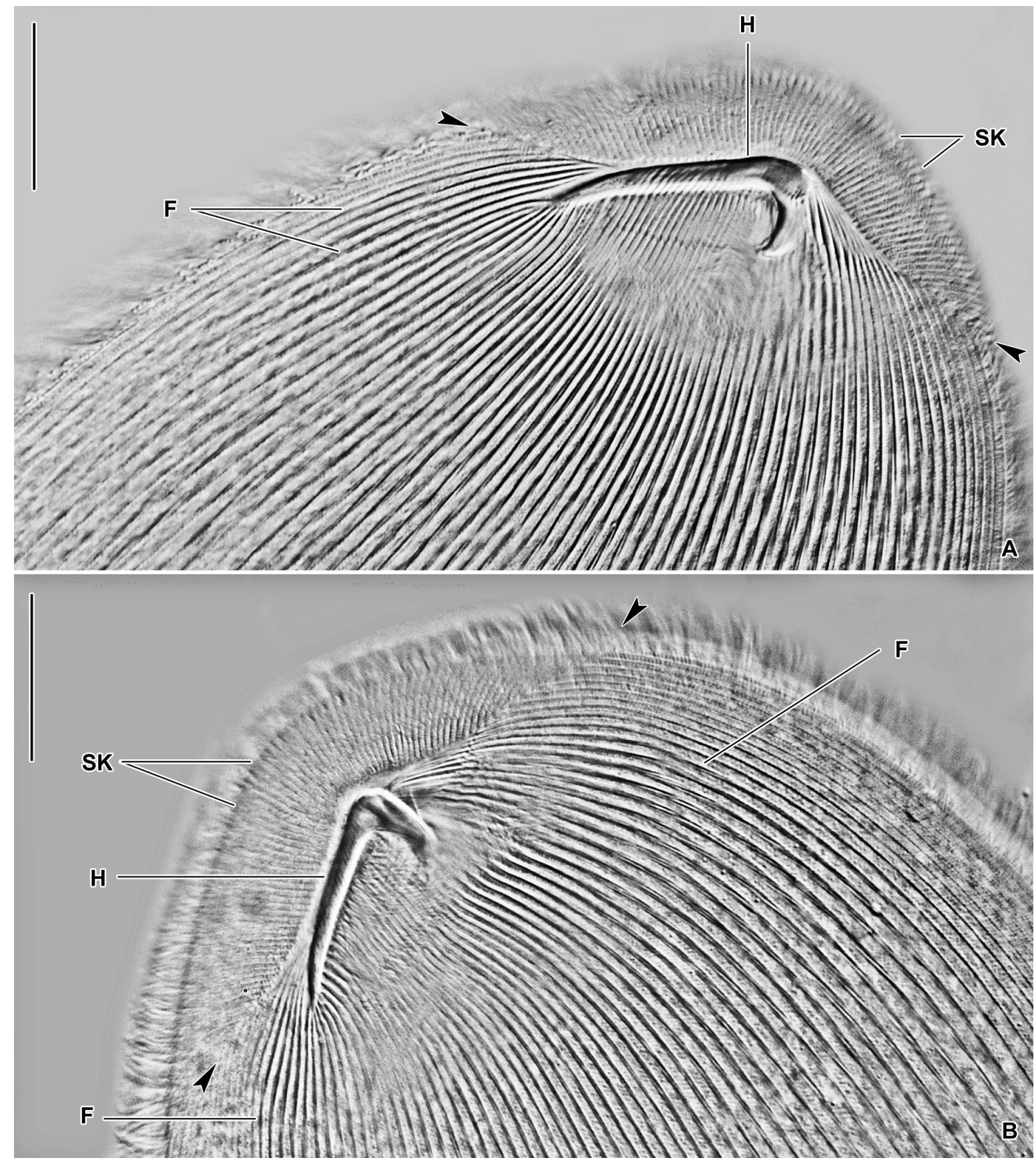

Fig. 5. A-B. Metaradiophrya lumbrici (Dujardin, 1841), Slovak specimens in vivo. Details of the anterior body portion, showing the fibrillar hook and its associated fibers. There are on average $6(5-7)$ fibers attached to the upper right side of the longer arm, on average 33 (30-37) fibers to the ventral side of the longer arm and on average $11(8-13)$ fibers to the left side of the shorter arm. Arrowheads mark the subapical suture extending from the right body margin over the fibrillar hook towards the left body margin. The somatic kineties above the suture run towards the anterior body end where they curve onto the dorsal body side to meridionally extend over its surface towards the posterior body end. On the other hand, the somatic kineties below the suture run meridionally over the ventral side towards the posterior body end. The ventral somatic kineties are lined with fibers attached to the fibrillar hook. Scale bars: $20 \mu \mathrm{m}$. 
in lateral view. A set of very distinct fibers is associated with the hook: on average 6 (5-7) fibers are attached to the upper right side of the longer arm, on average 33 (30-37) fibers to the ventral side of the longer arm and on average 11 (8-13) fibers to the left side of the shorter arm (Figs 2A-C, 3A, 5).

The nuclear apparatus is composed of a macronucleus and a micronucleus. The macronucleus is rodlike with both ends rounded. It begins about $27 \mu \mathrm{m}$ away from the anterior body margin and ends about $12 \mu \mathrm{m}$ above the posterior body margin. Its length spans a range from approximately 85 to $200 \mu \mathrm{m}$ and its width ranges from 8 to $18 \mu \mathrm{m}$, averaging at $13 \mu \mathrm{m}$. The macronuclear surface is smooth and without any irregularities, however, small vesicules appear in its vicinity in dying cells. The micronucleus is typically situated close to the mid-portion of the macronucleus. The shape of micronucleus is circular to elliptical and its diameter is approximately $7 \mu \mathrm{m}$. The central region of micronucleus appears homogenous and brighter than its margin in the differential interference optics and might represent a central nucleolus (Figs 2F-G, 3B-M, 4A, C-D).

There are invariably two staggered rows of contractile vacuoles, extending right and left of the macronucleus. Their number ranges from 3 to 12 with an average of 6 vacuoles in the right row and from 3 to 11 with an average of 6 vacuoles in the left row (Figs 2A, F-G, 3B, F-M, 4B-D). The cytoplasm is colorless and contains innumerable granules being ca $0.4 \mu \mathrm{m}$ across and rod-like bacteria being about 3-15 $\mu \mathrm{m}$ long (Figs 2G, 4C-D). The cortex is rigid and without any specific granules (Fig. 5). Swims moderately fast by rotation about the main body axis.

Somatic ciliature is holotrichous and composed of very densely ciliated and narrowly spaced kineties. The ventral ciliature is interrupted by a subapical suture that extends from the right body margin over the fibrillar hook towards the left body margin. Somatic kineties above the suture run towards the anterior body end where they curve onto the dorsal body side to meridionally extend over its surface towards the posterior body end. Somatic kineties below the suture run meridionally over the ventral side towards the posterior body end (Figs 2A-B, 3A, 4E-F, 5). The number of kineties on each body side ranges from 60 to 78. Lateral kineties form a right and a left subterminal suture in the posterior body region (Figs 2D-E, 4E).

\section{Occurrence}

Metaradiophrya lumbrici was detected exclusively in a group of anecic earthworms, namely, in L. terrestris at three localities: in gardens in the Súrska ulica street in Rendez and in the Jakubská ulica street in Rača as well as in floodplain soils in a riparian, willow-poplar forest near the Karlova Ves branch of the Danube River (Table 2). Ciliates were typically isolated from the middle part of the gastrointestinal tract, although very rarely one or two specimens were recorded also slightly above and below this gut region.

Metaradiophrya varians (de Puytorac, 1954)

Figs 6, 7

\section{Description}

The body size is about $110-180 \times 85-95 \mu \mathrm{m}$. The body shape is ovate to elliptical with an anterior body end rounded and posterior end broadly rounded to truncate. The cell is distinctly dorsoventrally flattened (Figs 6A, F-I, 7A, D). The fibrillar hook is localized about $10 \mu \mathrm{m}$ away from the anterior body end. Its longer arm measures on average $30 \mu \mathrm{m}$, while its shorter arm only $11 \mu \mathrm{m}$. The hook appears slightly flatter than in the previous species and the thickened base of the shorter arm has been never observed. There are 5 or 6 fibers attached to the upper right side of the longer arm, on average 26 (22-29) fibers to the ventral side of the longer arm and 11 or 12 fibers to the left side of the shorter arm (Figs 6A-C, 7B). 

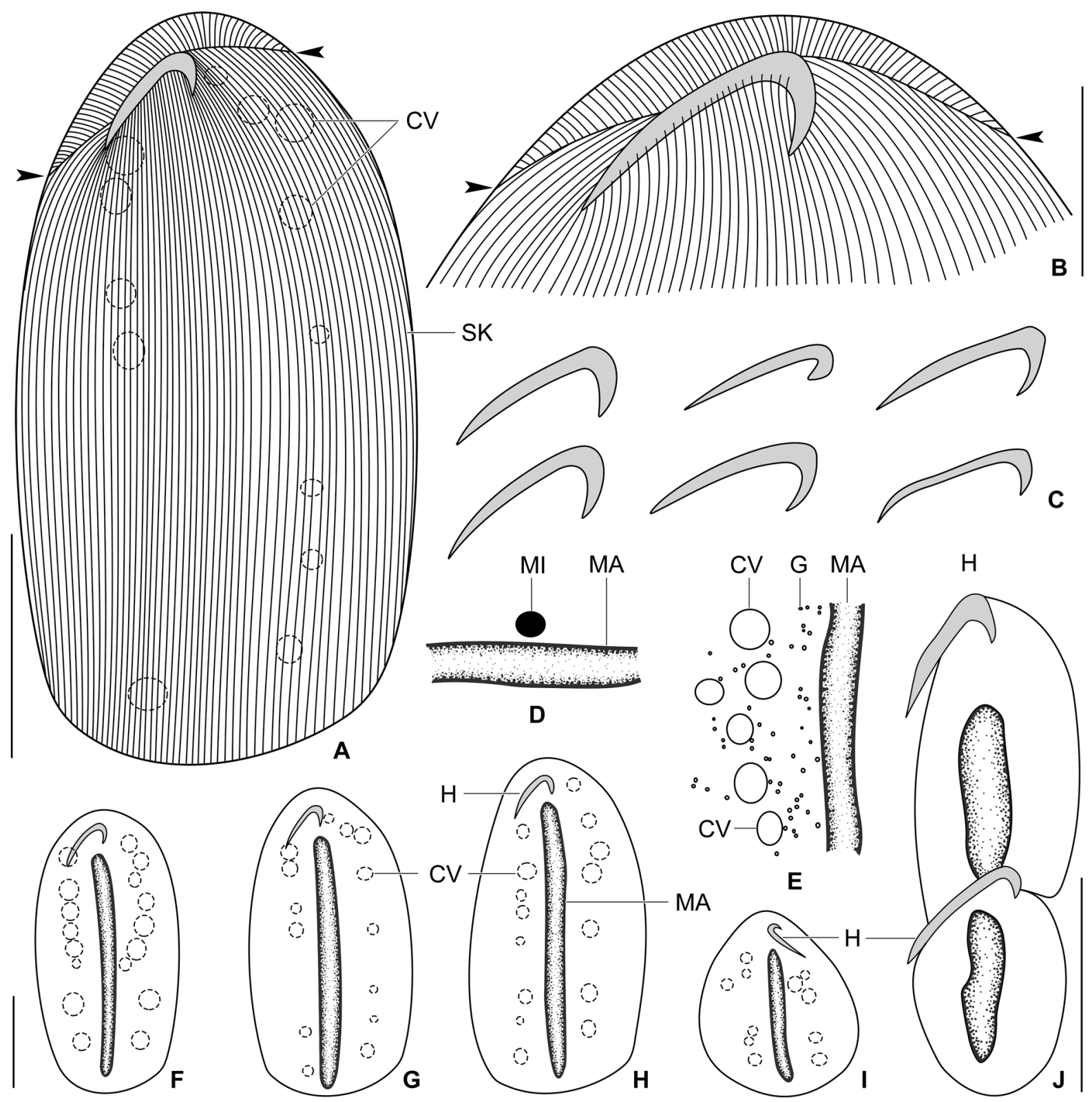

Fig. 6. Metaradiophrya varians (de Puytorac, 1954), Slovak specimens in vivo. A. Semi-schematic diagram of the ventral side, showing the localization of fibrillar hook, the arrangement of contractile vacuoles and the somatic ciliary pattern. Arrowheads mark the subapical suture extending from the right body margin over the fibrillar hook towards the left body margin. B. Detail of the anterior body portion, showing the fibrillar hook and its associated fibers. There are 5 or 6 fibers attached to the upper right side of the longer arm, on average 26 (22-29) fibers to the ventral side of the longer arm and 11 or 12 fibers to the left side of the shorter arm. C. Shape variants of fibrillar hooks. The longer arm of the hook measures on average $30 \mu \mathrm{m}$, while the shorter arm only $11 \mu \mathrm{m}$. D-E. The macronucleus is rodlike and accompanied by an elliptical micronucleus. F-I. Variability of body shape and size as well as of the contractile vacuole and nuclear apparatus. There are two staggered rows of contractile vacuoles arranged along the left and right side of the macronucleus. Drawn to scale. J. Ventral view, showing a late divider. Scale bars: A, F-J $=50 \mu \mathrm{m} ; \mathrm{B}=20 \mu \mathrm{m}$. 


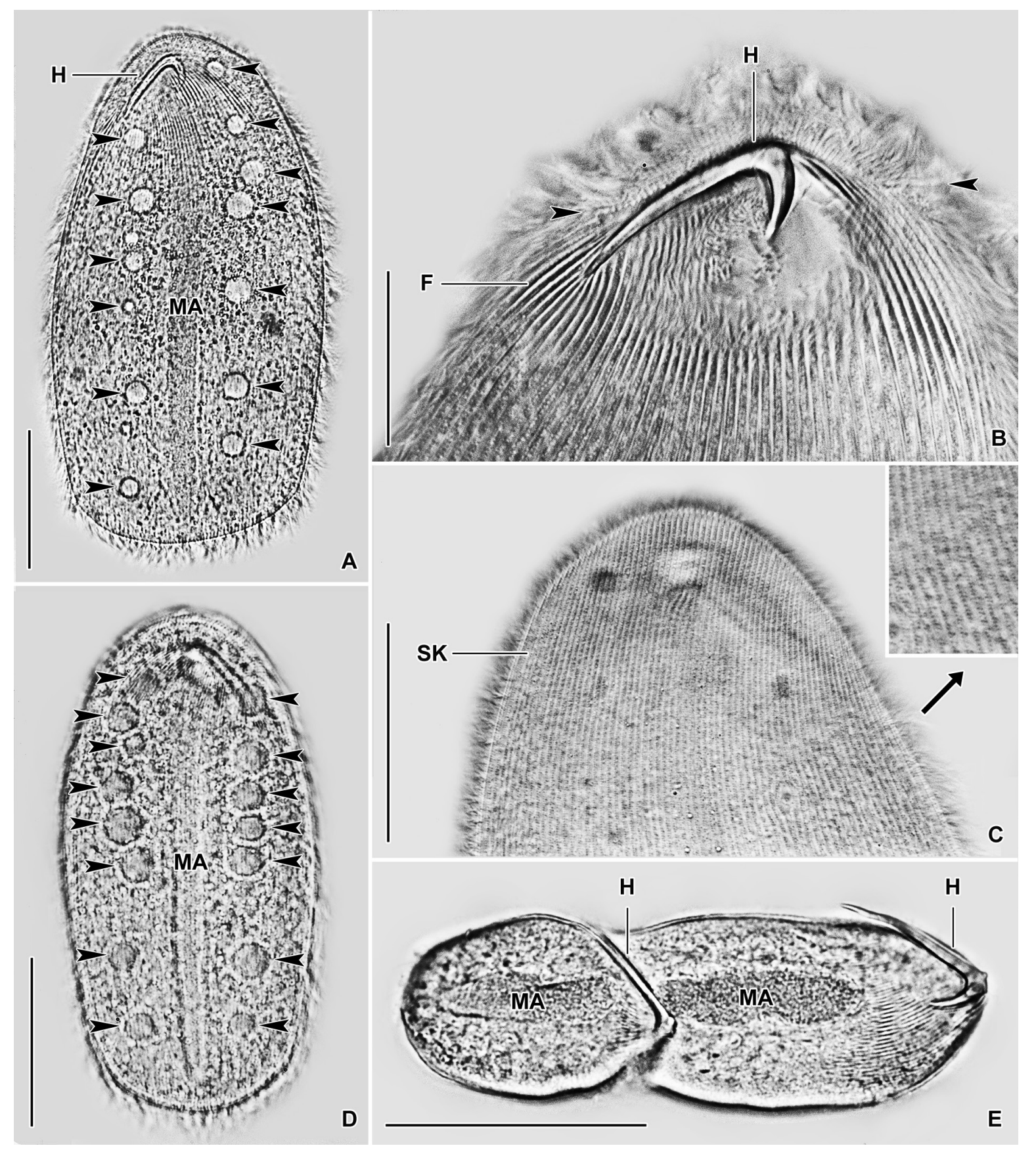

Fig. 7. Metaradiophrya varians (de Puytorac, 1954), Slovak specimens in vivo. A, D. Ventral view of representative specimens, showing the typical body shape, localization of the fibrillar hook, the long rodlike macronucleus and two staggered rows of contractile vacuoles (arrowheads). B. Detail of the anterior body portion, showing the fibrillar hook and its associated fibers. There are 5 or 6 fibers attached to the upper right side of the longer arm, on average 26 (22-29) fibers to the ventral side of the longer arm and 11 or 12 fibers to the left side of the shorter arm. Arrowheads mark the subapical suture extending from the right body margin over the fibrillar hook towards the left body margin. C. Dorsal view, showing the somatic kineties. The ciliary rows are narrowly arranged and are composed of very densely spaced basal bodies (left inset). E. Ventral view, showing a late divider. Scale bars: A, C-E $=50 \mu \mathrm{m} ; \mathrm{B}=20 \mu \mathrm{m}$. 
The nuclear apparatus consists of a single macronucleus and a single micronucleus. The macronucleus commences on average $25 \mu \mathrm{m}$ away from the anterior body end and terminates on average $11 \mu \mathrm{m}$ away from the posterior body end. The size of macronucleus is about $80-140 \times 10-15 \mu \mathrm{m}$. The macronucleus extends through cell's midline. The micronucleus reaches a diameter of 6-8 $\mu \mathrm{m}$ and is situated close to the macronucleus about in its mid-portion (Figs 6D-I, 7A, D).

There are two staggered rows of contractile vacuoles arranged along the right and left side of the macronucleus: 5-8 vacuoles in the right row and 6 or 7 vacuoles in the left row (Figs 6A, E-I, 7A, D). The cytoplasm is colorless and studded with granules about $0.5 \mu \mathrm{m}$ across. The cortex is rigid and without granules (Fig. 7B). Swims moderately fast by rotation about the main body axis.

Somatic ciliature is holotrichous and composed of very densely ciliated and narrowly spaced kineties. The ventral ciliature is interrupted by a subapical suture extending from the right body margin over the fibrillar hook to the left body margin. Somatic kineties above the suture run towards the anterior body end where they curve onto the dorsal body side to meridionally extend over its surface towards the posterior body end. Somatic kineties below the suture run meridionally over the ventral side towards the posterior body end (Figs $6 \mathrm{~A}-\mathrm{B}, 7 \mathrm{~B}-\mathrm{C}$ ). The number of ventral kineties ranges from 50 to 64 on the ventral side and from 53 to 64 on the dorsal side. There is a subterminal suture on the left and the right side of the body.

\section{Occurrence}

Metaradiophrya varians was solely recorded in the epigeic E. fetida at two comparatively distant localities, i.e., in compost heaps in the Jakubská ulica street in Rača and in the Botanical Garden of Comenius University (Fig. 1; Table 2). Metaradiophrya varians inhabited only the middle part of the gastrointestinal tract and there were usually ten exemplars per earthworm. Our data on occurrence of $M$. varians and $M$. lumbrici indicate that both species are specialized on different ecological groups of host oligochaetes. The ecologically different $L$. terrestris and $E$. fetida never contained the same species of Metaradiophrya, even when they originated from closely situated localities or when they were cocultivated in the laboratory.

Family Anoplophryidae Cépède, 1910

Genus Anoplophrya Stein, 1860

Anoplophrya lumbrici (Schrank, 1803)

Figs 8, 9

\section{Description}

The body size is about $50-120 \times 35-100 \mu \mathrm{m}$, with an average of $90 \times 60 \mu \mathrm{m}$. The shape is broadly elliptical to elliptical with both ends rounded. The cell is distinctly dorsoventrally flattened (Figs 8A, E-I, 9A-B, D).

The nuclear apparatus consists of a single macronucleus and a single micronucleus. The macronucleus begins about $11 \mu \mathrm{m}$ away from the anterior body end and extends through the cell's midline. The size of macronucleus varies from about 30-95 $\times 5-15 \mu \mathrm{m}$, with an average of $72 \times 9 \mu \mathrm{m}$. The macronuclear surface is smooth to slightly irregular. In dying cells, the macronucleus diminishes in size leaving behind a conspicuous hyaline envelope. The macronucleus sometimes also fragments within the envelope in postmortem cells. The micronucleus is situated conspicuously far away from the macronucleus, namely, near the middle of the left body margin and always opposite to the row of contractile vacuoles. The micronucleus is globular and approximately $5 \mu \mathrm{m}$ in diameter (Figs 8A, D-I, 9A-D). 


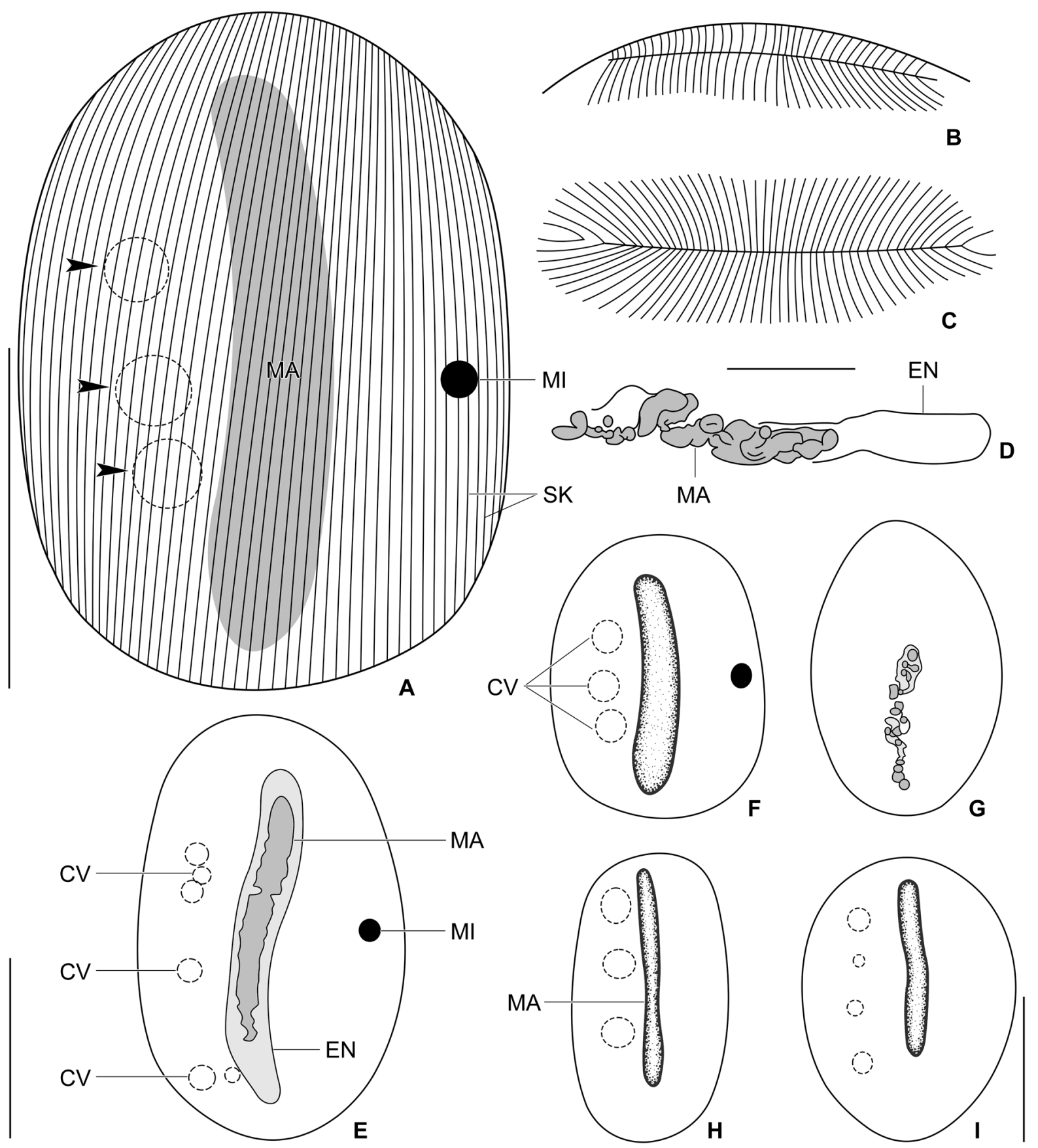

Fig. 8. Anoplophrya lumbrici (Schrank, 1803), Slovak specimens in vivo. A. Semi-schematic diagram of the ventral side, showing the nuclear apparatus, the arrangement of contractile vacuoles (arrowheads) and the somatic ciliary pattern. B-C. Details of the anterior and posterior body pole, showing the apical and the terminal suture. D. In dying cells, the macronucleus diminishes in size leaving behind a conspicuous hyaline envelope. The macronucleus sometimes also fragments within the envelope in postmortem cells. E-I. Variability of body shape and size as well as of the contractile vacuole and nuclear apparatus. The micronucleus is situated conspicuously far away from the macronucleus, namely, near the middle of the left body margin and always opposite to the row of contractile vacuoles. Drawn to scale. Scale bars: A, $\mathrm{E}-\mathrm{I}=50 \mu \mathrm{m} ; \mathrm{D}=20 \mu \mathrm{m}$. 

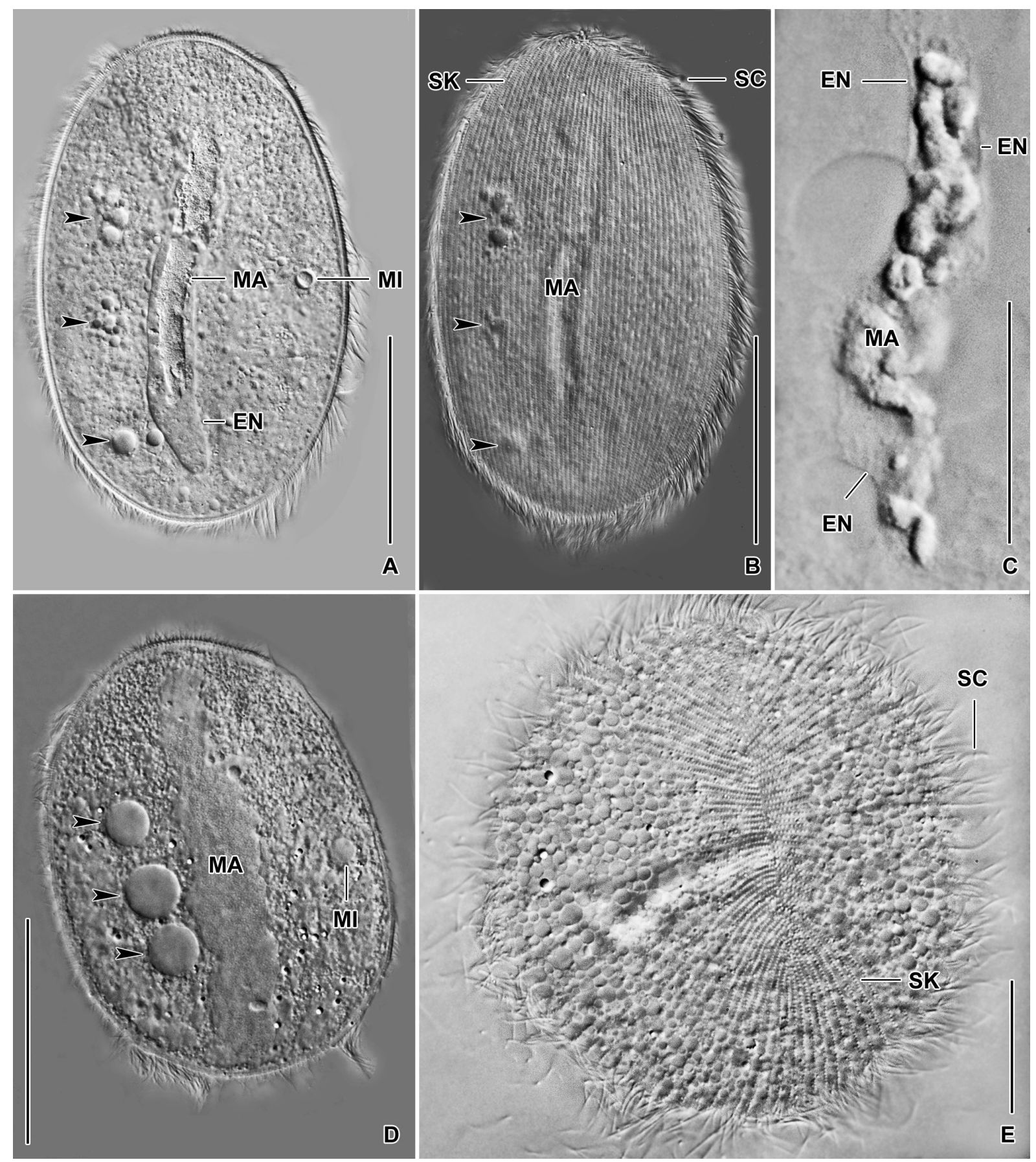

Fig. 9. Anoplophrya lumbrici (Schrank, 1803), Slovak specimens in vivo. A, D. Optical sections, showing the general body organization. The body is elliptical with both ends rounded. The macronucleus is rodlike and extends through the cell's midline. The micronucleus is situated conspicuously far away from the macronucleus, namely, near the middle of the left body margin and always opposite to the row of contractile vacuoles (arrowheads). B. Ventral view, showing the somatic ciliary pattern. Arrowheads denote the contractile vacuoles which originate by fusion of three to five vesicules. C. In dying cells, the macronucleus diminishes in size leaving behind a conspicuous hyaline envelope. The macronucleus sometimes also fragments within the envelope in postmortem cells. E. Frontal view, showing the apical suture. Scale bars: A-B, D $=50 \mu \mathrm{m} ; \mathrm{C}, \mathrm{E}=20 \mu \mathrm{m}$. 
There is only a single row of contractile vacuoles extending along the right cell margin. The number of vacuoles is three or four and their size ranges from 4 to $11 \mu \mathrm{m}$ in diastole. A contractile vacuole originates by fusion of three to five vesicules (Figs 8A, E-F, H-I, 9A-B, D). The cytoplasm is colorless and contains innumerable granules being about $1.5 \mu \mathrm{m}$ across. The cortex is semi-rigid and without specific granules. Swims moderately fast by rotation about the main body axis.

The somatic ciliature is holotrichous and composed of meridionally extending kineties over both cell sides. The number of ventral kineties varies from 30 to 50, averaging at 42 . The number of dorsal kineties almost matches the number on the ventral side (30-51, on average 43). Somatic kineties are composed of very densely arranged basal bodies, i.e., intrakinetal distance is only $1.3 \mu \mathrm{m}$ (Figs $8 \mathrm{~A}, 9 \mathrm{~B})$. There is an apical and a terminal suture at the anterior and the posterior pole where individual somatic kineties begin and terminate, respectively (Figs $8 \mathrm{~B}-\mathrm{C}, 9 \mathrm{E}$ ).

\section{Occurrence}

Anoplophrya lumbrici was recorded only in the anecic L. terrestris at three localities: gardens at the Šúrska ulica street in Rendez and at the Jakubská ulica street in Rača as well as in floodplain soils in a riparian, willow-poplar forest near the Karlova Ves branch of the Danube River (Table 2). Ciliates were typically isolated from the middle part of the gastrointestinal tract, although very rarely some specimens were recorded also below this gut region.

Anoplophrya vulgaris de Puytorac, 1954

Figs $10,11 \mathrm{~A}-\mathrm{C}$

\section{Description}

The body size is about $100-145 \times 60-80 \mu \mathrm{m}$. The body shape is broadly elliptical to elliptical with both ends rounded. The cell is distinctly dorsoventrally flattened (Figs 10A, D-F, 11A-B).

The nuclear apparatus is composed of a single macronucleus and a single micronucleus. The macronucleus begins about $6 \mu \mathrm{m}$ away from the anterior body end extends through the cell's midline into the posterior body region. The length of macronucleus varies from 80 to $110 \mu \mathrm{m}$ and its width ranges from 9 to $18 \mu \mathrm{m}$. The macronuclear surface is smooth. The macronucleus diminishes in size leaving behind a conspicuous hyaline envelope in dying cells. The micronucleus is situated conspicuously far away from the macronucleus, namely, near the middle of the left body margin and opposite to the row of contractile vacuoles. The micronucleus is globular and approximately $4 \mu \mathrm{m}$ in diameter (Figs 10A, D-F, 11A-B).

There is a single row of contractile vacuoles arranged along the right cell margin. It is composed of three or four vacuoles being 5-9 $\mu \mathrm{m}$ across during diastole (Figs 10A, D-F, 11A-B). The cytoplasm is colorless and studded with granules measuring approximately $0.5-1.0 \mu \mathrm{m}$ in diameter. The cortex is semi-rigid and without specific granules. Swims moderately fast by rotation about the main body axis.

Somatic ciliature is holotrichous and composed of kineties meridionally extending over both cell sides. There are on average 34 (24-45) kineties on each body side. Individual kineties are very narrowly arranged and the interkinetal distance ranges from about 0.6 to $2.0 \mu \mathrm{m}$. Likewise, basal bodies are very narrowly spaced within kineties and the intrakinetal distance is ca $1 \mu \mathrm{m}$. There is an apical and a terminal suture at each cell pole where individual somatic kineties commence and terminate, respectively (Figs 10A-C, 11B-C). 


\section{Occurrence}

Anoplophrya vulgaris was recorded in two species of epigeic earthworms, viz., in E. fetida and D. veneta. Ciliate 18S rRNA gene sequences originated from both hosts were identical. Host earthworms came from a compost heap in the Botanical Garden of Comenius University and at the Jakubská ulica street in Rača as well as from humous soil with a high content of decomposing plant material from a garden at the foothill of the Male Karpaty Mts. (Table 2). Endosymbiotic ciliates typically occurred in the middle part of the gastrointestinal tract. There were usually 10 to 15 endosymbionts per host.

\section{Anoplophrya ef. nodulata (Dujardin, 1841)}

Figs 11D-E, 12

\section{Description}

Only five specimens were found, three were morphologically examined and two were used for molecular analyses. Therefore, the description is rather incomplete. The body size is about $100 \times 50 \mu \mathrm{m}$. The

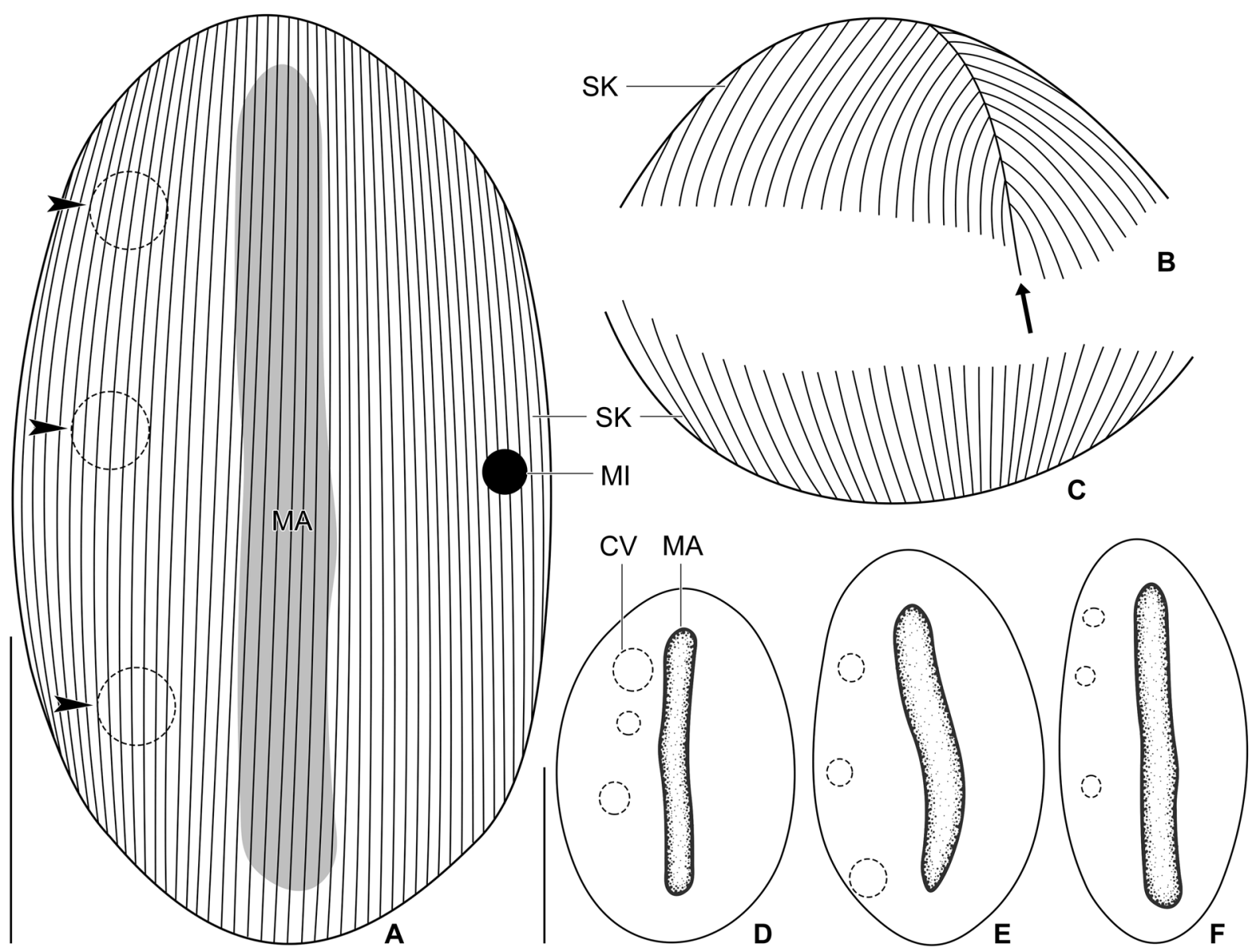

Fig. 10. Anoplophrya vulgaris de Puytorac, 1954, Slovak specimens in vivo. A. Semi-schematic diagram of the ventral side, showing the nuclear apparatus, the arrangement of contractile vacuoles (arrowheads) and the somatic ciliary pattern. B-C. Details of the anterior body pole and the posterior body region, showing the course of the somatic kineties. Arrow denotes the apical suture. D-F. Variability of body shape and size as well as of the contractile vacuole and nuclear apparatus. Drawn to scale. Scale bars: $50 \mu \mathrm{m}$. 
shape is ovate to broadly fusiform with both ends rounded. The cell is distinctly dorsoventrally flattened (Figs 11D-E, 12).

The macronucleus begins about $10 \mu \mathrm{m}$ away from the anterior body end and extends through the cell's midline. Its size is usually $75 \times 13 \mu \mathrm{m}$. The macronuclear surface was slightly irregular. The macronucleus displays similar postmortem changes as in the two previous Anoplophrya species, i.e., it slightly diminishes in size leaving behind a hyaline envelope. The micronucleus was not observed (Figs 11D-E, 12).

There are two staggered rows of contractile vacuoles extending along the right and left side of the macronucleus: 3-6 vacuoles in the right row and 3-5 vacuoles in the left row. The average size of vacuoles ranged from 5-7 $\mu \mathrm{m}$ during diastole (Figs 11D-E, 12). The cytoplasm is colorless and filled with granules being approximately $1 \mu \mathrm{m}$ in diameter. The cortex is semi-rigid and without specific granules. Swims moderately fast by rotation about the main body axis.
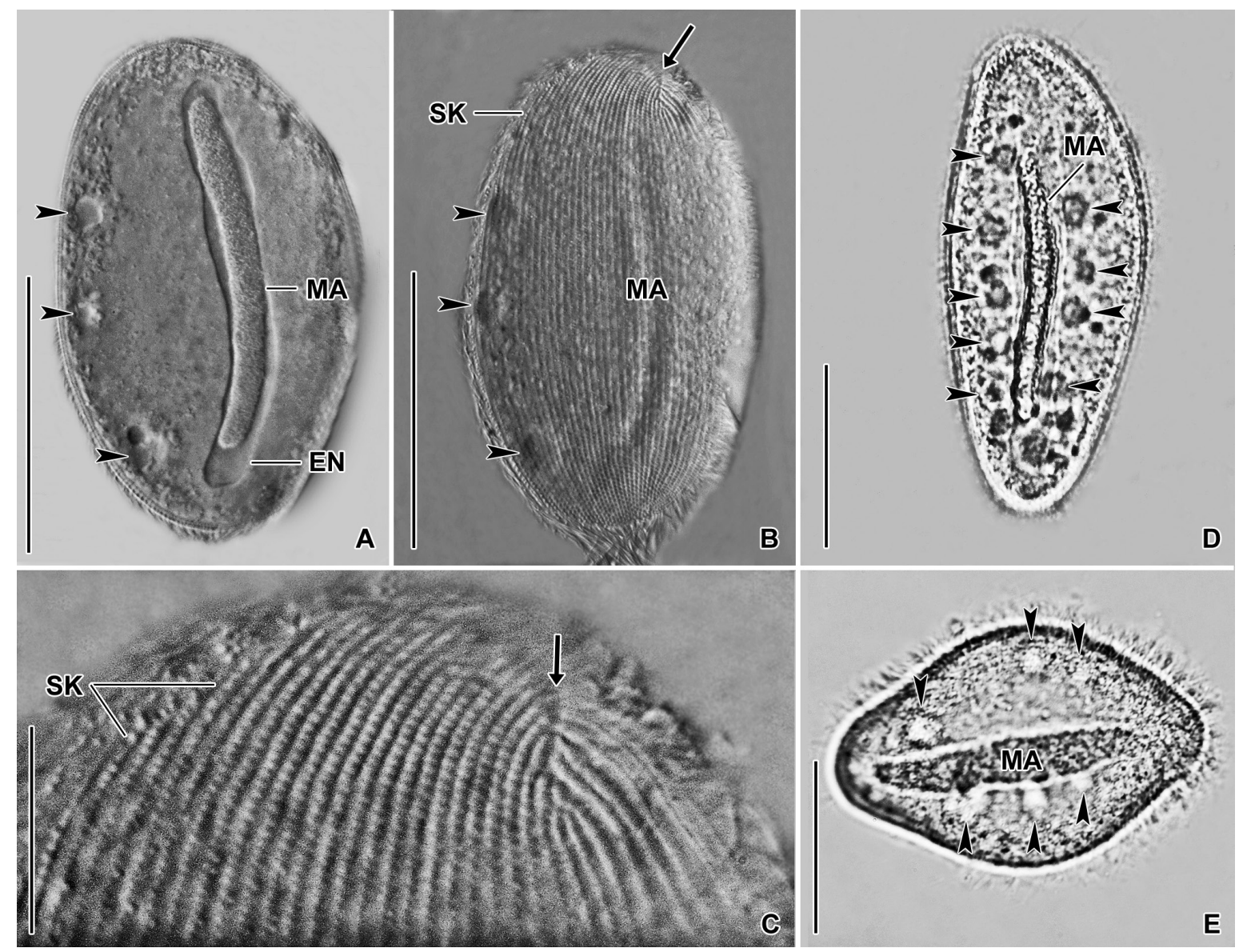

Fig. 11. Anoplophrya vulgaris de Puytorac, 1954 (A-C) and Anoplophrya nodulata (Dujardin, 1841) (D-E), Slovak specimens in vivo. A-B. Ventral views, showing the nuclear apparatus, the arrangement of contractile vacuoles (arrowheads) and the somatic ciliary pattern. Arrow marks the apical suture. C. Detail of the anterior body region, showing the apical suture (arrow) and the meridional ciliary rows composed of very narrowly arranged basal bodies. D-E. Optical sections, showing the general body organization. The body is ovate to broadly fusiform with both ends rounded. The macronucleus is rodlike with slightly irregular surface. There are two rows of contractile vacuoles (arrowheads). Scale bars: A-B, D-E $=50 \mu \mathrm{m} ; \mathrm{C}=20 \mu \mathrm{m}$. 
Somatic ciliature is holotrichous and composed of densely ciliated meridional kineties. Due to the low number of ciliates, their number on the ventral and dorsal side could not be determined.

\section{Occurrence}

Anoplophrya nodulata was detected only in two out of five specimens of Octolasion tyrtaeum investigated. This endogeic earthworm originated from the upper $50 \mathrm{~cm}$ peat layer in the riparian zone of the Rašelinisko Pond in the vicinity of the Pusté Úl'any Village in the Galanta District (Table 2). Endosymbiotic ciliates were found only in the central part of the oligochaete gastrointestinal tract. No other ciliates were recorded in the digestive system of $O$. tyrtaeum.

\section{Multivariate morphometric analyses}

Altogether, 16 quantitative features, a single qualitative character and two derived ratios were scored on 33 individuals belonging to four astome species: M. lumbrici, M. varians, A. lumbrici and A. vulgaris. Morphometric data were compiled in Table 3 and served to calculate Gower's pairwise similarities among ciliate specimens. Multidimensional scaling was performed on the pairwise Gower's coefficients, using the scikit-learn package in Python.

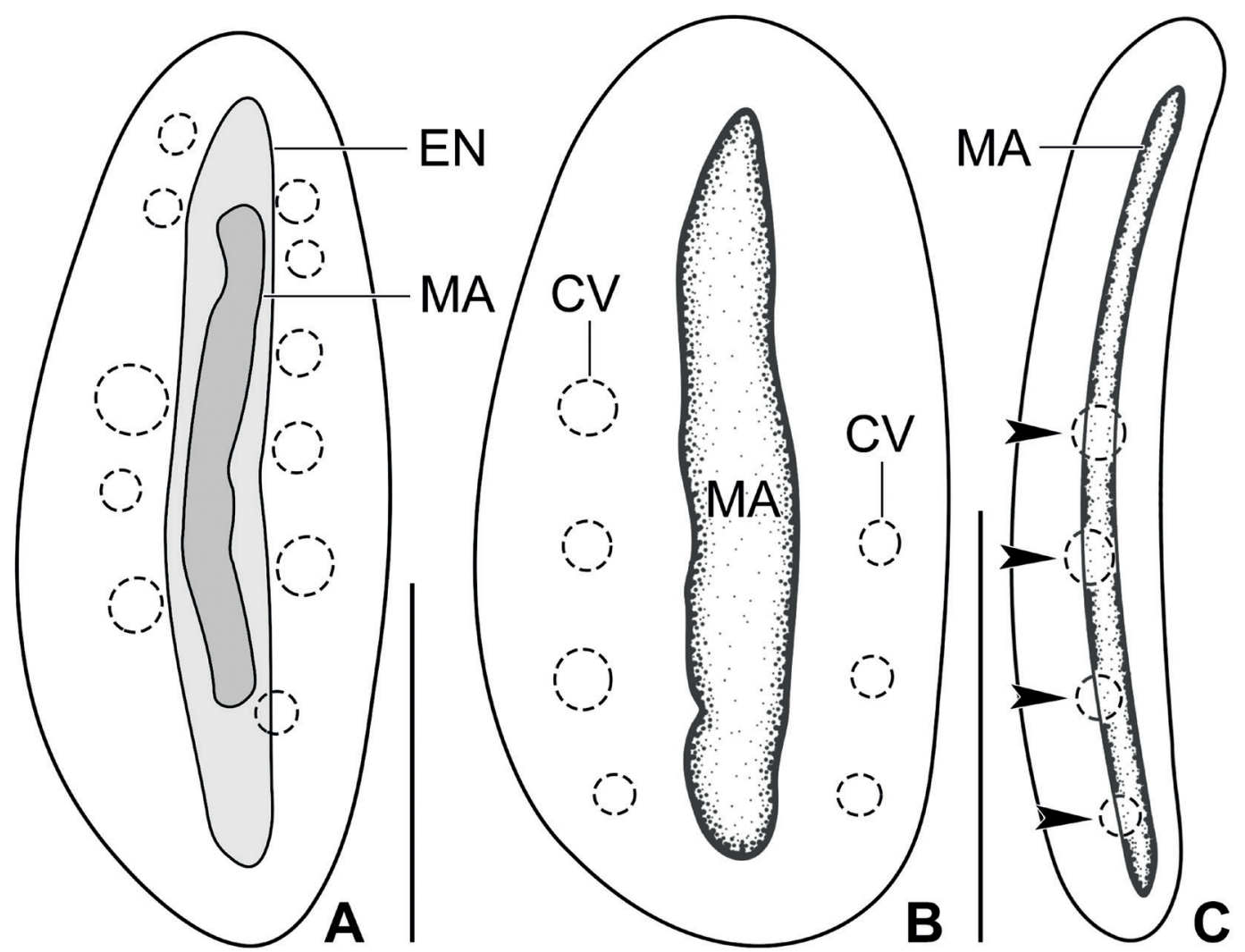

Fig. 12. Anoplophrya nodulata (Dujardin, 1841), Slovak specimens in vivo. A-B. Ventral views, showing the general body organization. The body is ovate with both ends rounded. The macronucleus is rod-like and extends through the cell's midline. In dying cells, the macronucleus diminishes in size leaving behind a conspicuous hyaline envelope. There are two rows of contractile vacuoles, extending right and left of the macronucleus. C. Lateral view, showing the distinctly dorsoventrally flattened body. Arrowheads denote the right row of contractile vacuoles. Scale bars: $50 \mu \mathrm{m}$. 
Two mutually isolated groups, species of Metaradiophrya and Anoplophrya, were distinctly separated along the first and the second ordination axis (Fig. 13). However, individual species within each genus were not distinctly segregated. Specifically, two specimens of $M$. varians were intermingled with some M. lumbrici individuals, indicating that the intraspecific variability in most morphometric features of the latter species is so wide that M. varians at least partially falls within its range. Nevertheless, both species can be unequivocally distinguished by a single morphometric character, the number of fibers associated with the ventral side of the longer arm of the fibrillar hook. Specifically, there are 30-37 (on average 33) fibers in M. lumbrici and 22-29 (on average 26) fibers in M. varians (Table 3).

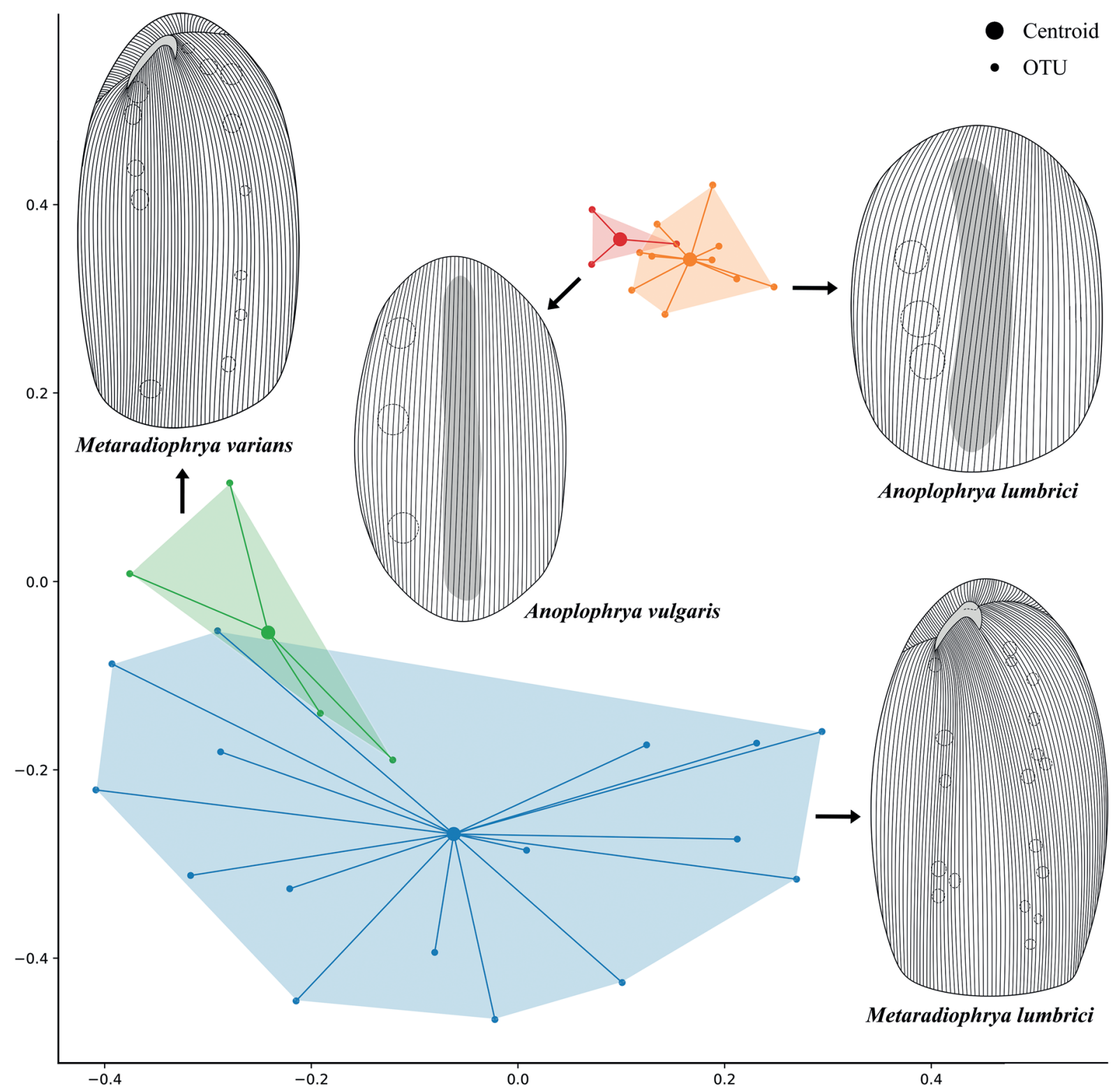

Fig. 13. Multidimensional scaling of 33 individuals based on pairwise Gower's similarities calculated from 16 quantitative features, a single qualitative character and two derived ratios. 
OBERT T. \& VĎAČNÝ P., Morphology and phylogeny of five astome ciliates

A similar mixed pattern was revealed also for the two species of Anoplophrya. Anoplophrya lumbrici was depicted as a comparatively more variable species, somewhat overlapping with the cluster of A. vulgaris. The latter species, however, showed a trend of at least partial separation from $A$. lumbrici in the ordination diagram (Fig. 13). The morphometric data indicate that $A$. vulgaris is slightly larger and narrower than $A$. lumbrici $(100-145 \times 60-80 \mu \mathrm{m}$ vs 50-120 $\times 35-100 \mu \mathrm{m})$, although their size ranges overlap distinctly.

\section{Molecular characterization and phylogenetic position of ciliates isolated from lumbricid earthworms}

In total, 19 new 18S rRNA gene sequences were obtained from M. lumbrici (eight sequences), $M$. varians (four sequences), A. lumbrici (two sequences), A. vulgaris (three sequences) and $A$. nodulata (two sequences). Their length, GC content and GenBank accession numbers are summarized in Table 4. Intraspecies sequence similarities were $100 \%$, except for M. lumbrici where one out of the 1762 nucleotide positions was polymorphic. Namely, two KR-specimens (10/1 and 10/C) had guanine at the position 796 while the rest of KR-exemplars as well as all other M. lumbrici individuals displayed adenine there.

Genetic distances estimated under the maximum composite likelihood model showed that the evolutionary divergence between $M$. lumbrici and $M$. varians is $0.0138 \pm 0.0032$. A slightly larger distance was revealed between $A$. lumbrici and $A$. vulgaris $(0.0168 \pm 0.0037)$. However, evolutionary divergences between species of Metaradiophrya and Anoplophrya were more than two times greater ranging from 0.0304 to 0.0380 . Anoplophrya nodulata was revealed as the most divergent taxon from both species of Metaradiophrya (0.0608-0.0627) as well as from the two other species of Anoplophrya (0.0717-0.0752) (Table 5).

To determine the phylogenetic position of these five ciliate species, Bayesian and maximum likelihood (ML) as well as neighbor-joining (NJ) analyses were conducted (Figs 14-15). The newly obtained sequences were classified into the paraphyletic subclass Astomatia of the class Oligohymenophorea. Paraphyly of the Astomatia was caused in that the astome Haptophrya planariarum (von Siebold, 1839) isolated from flatworms clustered with species of the scuticociliate genus Dexiotricha with full statistical support both in the Bayesian and ML analyses. All astomes isolated from annelids formed a strongly statistically supported monophylum (posterior probability 1.00, 99\% ML bootstrap). Astomes from polychaetes (Durchoniella spp.) branched off first and were followed by a paraphyletic assemblage of astomes from endogeic oligochaetes (Almophrya de Puytorac et Dragesco, 1969, Anoplophrya nodulata, Eudrilophrya de Puytorac, 1969, Metaracoelophrya de Puytorac et Dragesco, 1969, Njinella Ngassam, 1983 and Paraclausilocola Fokam et al., 2011). Lineages of astome ciliates from anecic (M. lumbrici and $A$. lumbrici) and epigeic ( $M$. varians and A. vulgaris) earthworms were nested within the crown radiation of this paraphyletic cluster (Figs 14-15).

Monophylies of M. varians, A. lumbrici (including A. marylandensis Conklin, 1930), A. vulgaris and A. nodulata were fully statistically supported in Bayesian, ML and NJ analyses of the general and detailed alignment (Figs 14-15). However, monophyly of M. lumbrici was fully statistically supported only in NJ analyses (100\% bootstrap) of the detailed alignment (Fig. 15) and strongly in ML analyses ( $91 \%$ bootstrap) of the general alignment (Fig. 14), while it was left unsupported in ML analyses of the detailed alignment and in the Bayesian inferences of both alignments. Specifically, specimens of $M$. lumbrici clustered together in Bayesian analyses of the general alignment, but with a statistically insignificant posterior probability of 0.91 (Fig. 14). On the other hand, in the Bayesian tree inferred from the detailed alignment, specimens of $M$. lumbrici were placed in a basal polytomy of a cluster containing a fully statistically supported clade of A. lumbrici and A. vulgaris. This whole assemblage, however, obtained a statistically insignificant posterior probability of 0.82 (Fig. 14) and its relevance 


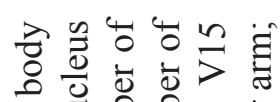

들

\它声实

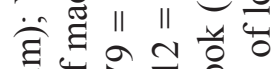

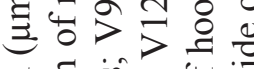

劳

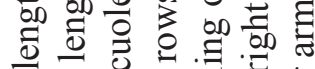

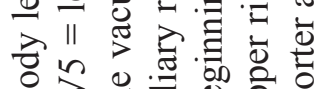

>

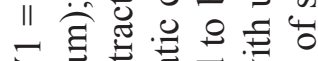

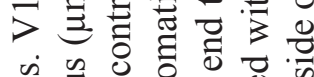

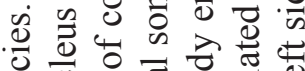

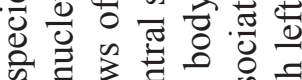

की

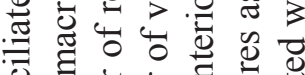

范㐫

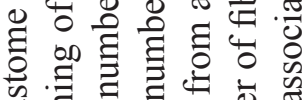

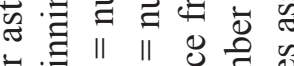

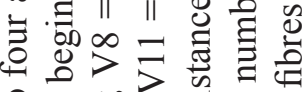

요에

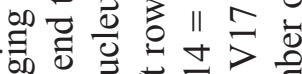

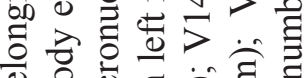

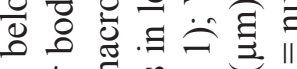

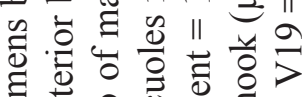

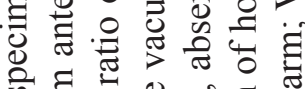

के

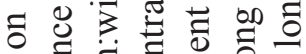

퓬

雪: 닝

플

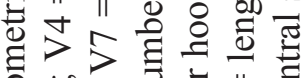

鱼前音

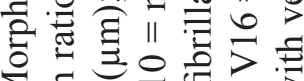

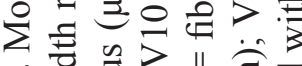

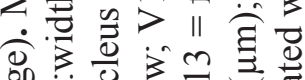

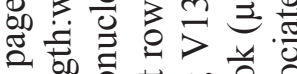

해

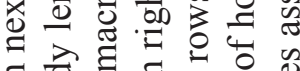

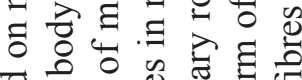

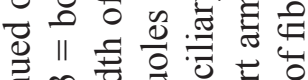

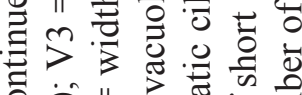
ठํㅠ

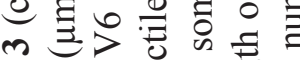

品苛焉

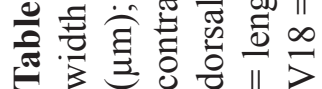

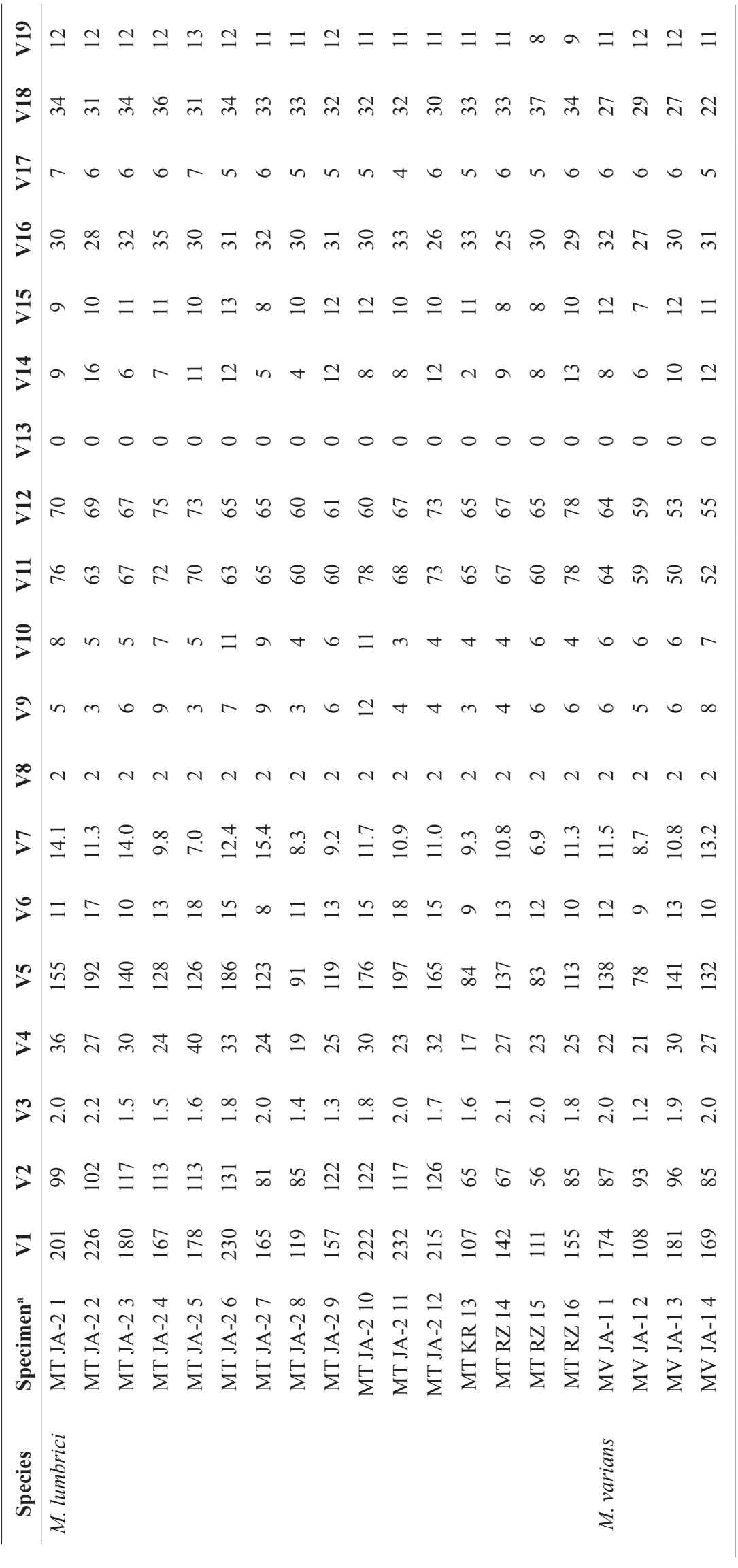




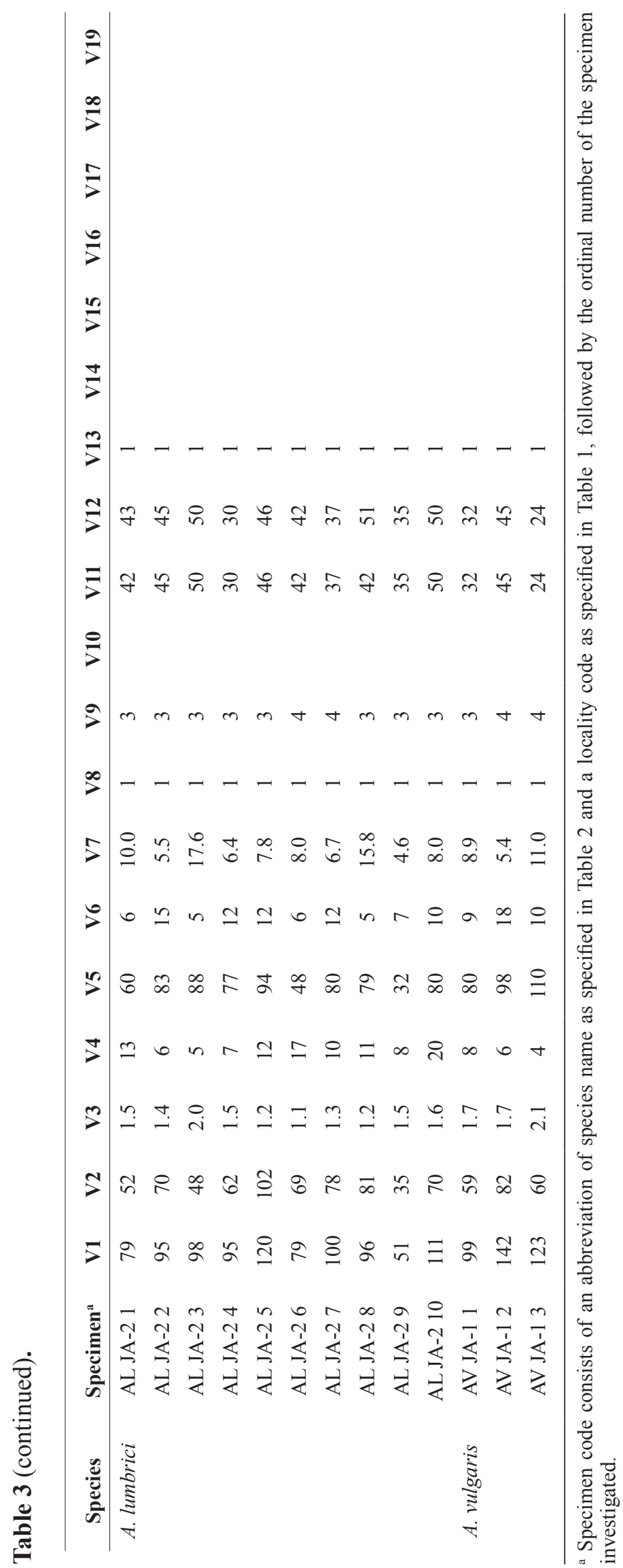




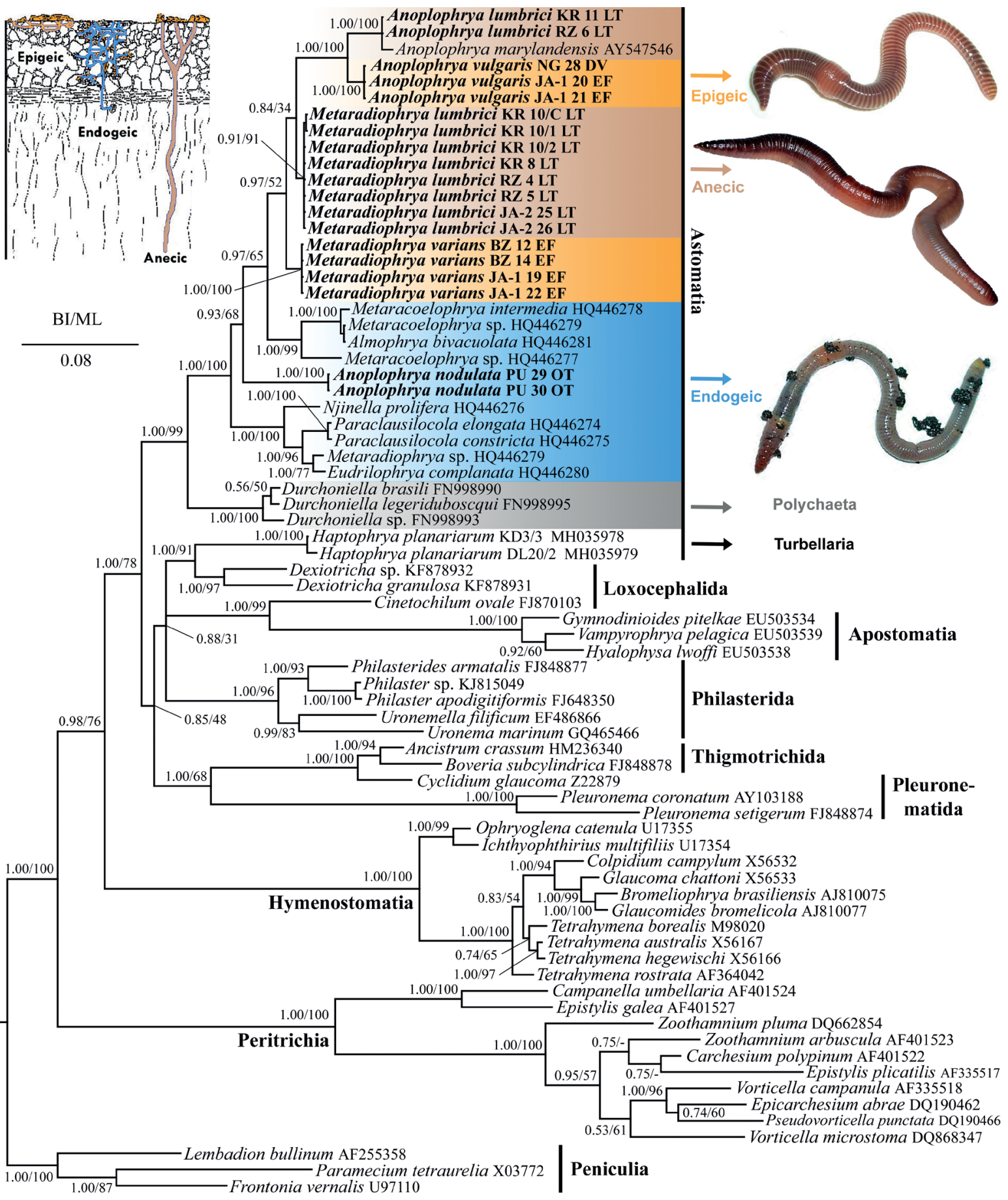

Fig. 14. Small subunit rRNA gene phylogenetic tree showing systematic positions of astome ciliates isolated from lumbricid earthworms. Posterior probabilities for Bayesian Inference (BI) and bootstrap values for Maximum Likelihood (ML) were mapped onto the 50\%-majority rule Bayesian consensus tree. Dashes indicate ML bootstrap values below 50\%. The phylogenetic tree suggests that the evolution of endosymbiotic astome ciliates has proceeded through a specialization to various ecological and systematic groups of their host organisms. Sequences in bold face were obtained during this study. For specimen codes and further details, see Table 4. The scale bar denotes eight substitutions per one hundred nucleotide positions. 


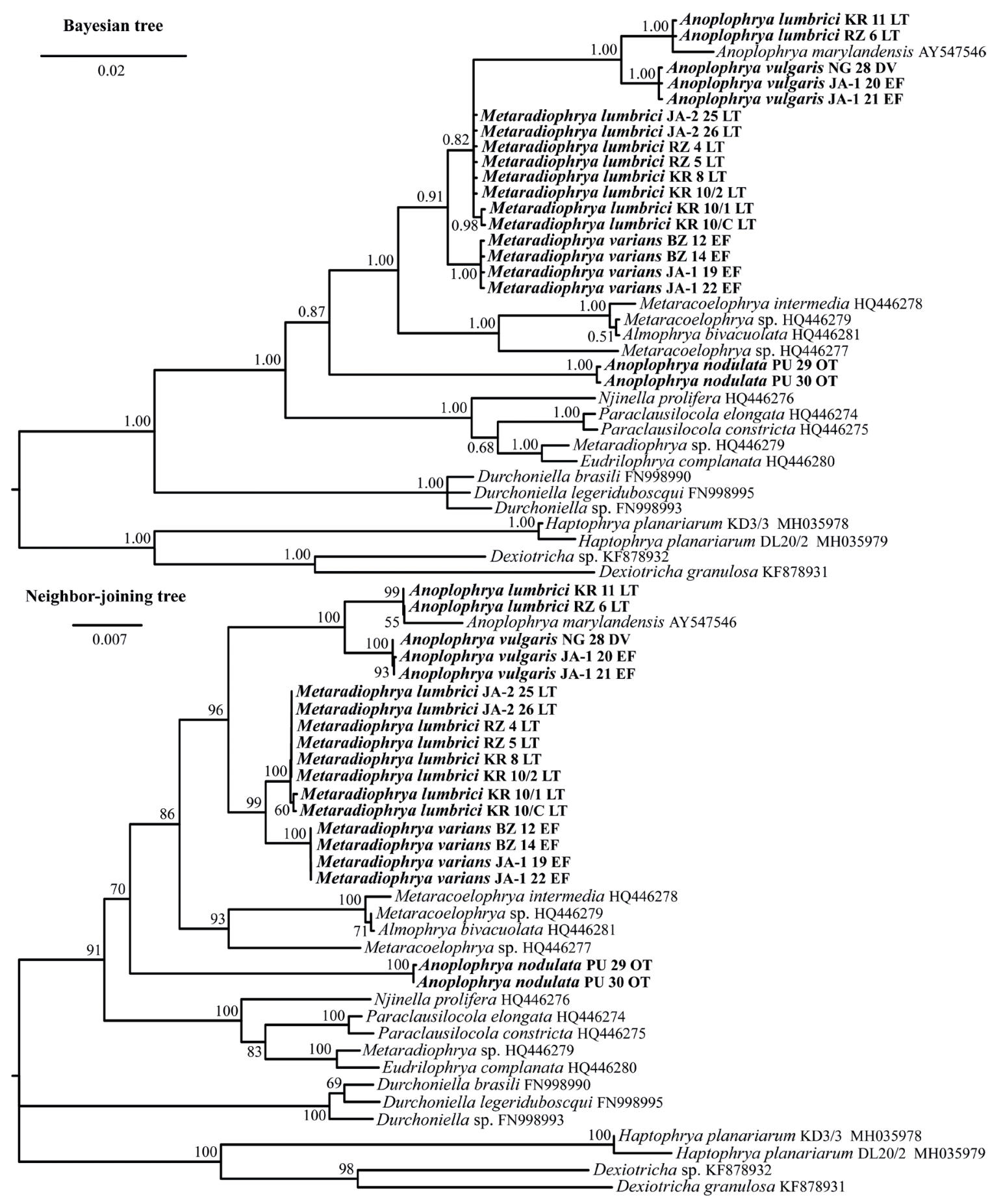

Fig. 15. Small subunit rRNA gene phylogenetic trees showing systematic positions of astome ciliates isolated from lumbricid earthworms. Posterior probabilities were mapped onto the 50\%-majority rule Bayesian consensus tree (upper panel) and bootstrap values onto the 50\%-majority rule neighbor-joining tree (lower panel). Sequences in bold face were obtained during this study. Note that there is a conflict between the Bayesian and the neighbor-joining tree in the position of specimens of Metaradiophrya Jankowski, 2007. However, according to tree topology tests, the branching pattern of the Bayesian tree is not significantly better than that of the neighbor-joining tree. The scale bar denotes fraction of substitutions. 
Table 4. Characterization of new $18 \mathrm{~S}$ rRNA gene sequences of astome ciliates obtained from lumbricid oligochaetes.

\begin{tabular}{lllcccc}
\hline Species & Specimen $^{\mathbf{a}}$ & Host species & Locality code $^{\mathbf{b}}$ & Length (nt) & GC (\%) & GenBank entry \\
\hline Anoplophrya lumbrici & KR 11 LT & L. terrestris & KR & 1754 & 43.84 & MN121061 \\
& RZ 6 LT & L. terrestris & RZ & 1754 & 43.84 & MN121062 \\
Anoplophrya nodulata & PU 29 OT & O. tyrtaeum & PU & 1758 & 43.86 & MN121063 \\
& PU 30 OT & O. tyrtaeum & PU & 1758 & 43.86 & MN121064 \\
Anoplophrya vulgaris & JA-1 20 EF & E. fetida & JA-1 & 1750 & 44.57 & MN121065 \\
& JA-1 21 EF & E. fetida & JA-1 & 1750 & 44.57 & MN121066 \\
& NG 28 DV & D. veneta & NG & 1750 & 44.57 & MN121067 \\
Metaradiophrya lumbrici & JA-2 25 LT & L. terrestris & JA-2 & 1762 & 44.61 & MN121068 \\
& JA-2 26 LT & L.terrestris & JA-2 & 1762 & 44.61 & MN121069 \\
& KR 8 LT & L. terrestris & KR & 1762 & 44.61 & MN121070 \\
& KR 10/1 LT & L. terrestris & KR & 1762 & 44.67 & MN121071 \\
& KR 10/2 LT & L. terrestris & KR & 1762 & 44.61 & MN121072 \\
& KR 10/C LT & L. terrestris & KR & 1762 & 44.67 & MN121073 \\
& RZ 4 LT & L. terrestris & RZ & 1762 & 44.61 & MN121074 \\
& RZ 5 LT & L. terrestris & RZ & 1762 & 44.61 & MN121075 \\
& BZ 12 EF & E. fetida & BZ & 1764 & 44.10 & MN121076 \\
& BZ 14 EF & E. fetida & BZ & 1764 & 44.10 & MN121077 \\
& JA-1 19 EF & E. fetida & JA-1 & 1764 & 44.10 & MN121078 \\
& JA-1 22 EF & E. fetida & JA-1 & 1764 & 44.10 & MN121079 \\
\hline Metaradiophrya varians & & & & &
\end{tabular}

a Specimen code consists of a locality code as specified in Table 1, an isolate code and an abbreviation of host species name (see Material and methods).

${ }^{\mathrm{b}}$ For locality codes, see Table 1.

should be therefore taken with great caution. Identical topology was revealed also in ML analyses of the detailed alignment $(-\ln L=5056.68)$ (data not shown). Due to the discrepancy between the topology of the NJ tree on the one hand and the Bayesian and ML trees on the other, statistical tree topology tests were conducted. They revealed that the monophyly of $M$. lumbrici and its sister-group relationship to $M$. varians $(-\ln \mathrm{L}=5059.33$ ) could not be rejected (Table 6). The conflict between the distance NJ tree and the Bayesian and ML trees was possibly caused by a plesiomorphic/homoplastic trap. Meteradiophrya lumbrici differed from M. varians in 25 nucleotide positions, but a comparison of 18S rRNA gene sequences of M. lumbrici with those of three species of Anoplophrya revealed that 19 out of the 25 variable nucleotide positions are either plesiomorphies or possibly homoplasies. Only six positions $(36,76,100,119,120,141)$ appear as molecular apomorphies of M. lumbrici (Fig. 16). This indicates that distance techniques might avoid the plesiomorphic/homoplastic trap when sequences of related species are highly similar (genetic distance between $M$. lumbrici and $M$. varians is only $0.0138 \pm 0.0032$; Table 5). On the other hand, Bayesian inference and maximum likelihood might not be resistant to the plesiomorphic/homoplastic trap when plesiomorphies/homoplasies significantly 
outnumber apomorphies. Therefore, taxonomic discrepancies in phylogenetic trees need to be analyzed also using distance methods and statistical tree topology tests.

\section{Discussion}

The gastrointestinal tract of earthworms from the oligochaete family Lumbricidae is inhabited by astomes belonging to only three genera, namely, Metaradiophrya, Anoplophrya and Maupasella (Heidenreich 1935; Lom 1961; de Puytorac 1972). There are several dozens of species in each genus and their identification is difficult because of comparatively few diagnostic morphologic features and lack of information about intraspecific variability and host range (e.g., Cépède 1910; Heidenreich 1935; Beers 1938; Williams 1942; Lom 1961; de Puytorac 1972). Because of these problems, most records of astome ciliates from lumbricid earthworms need to be taken with caution. Moreover, our integrative approach revealed that a combination of detailed microscopic observation, molecular data as well as identity and ecological group of host organisms is indispensable for reliable identification of astomes.

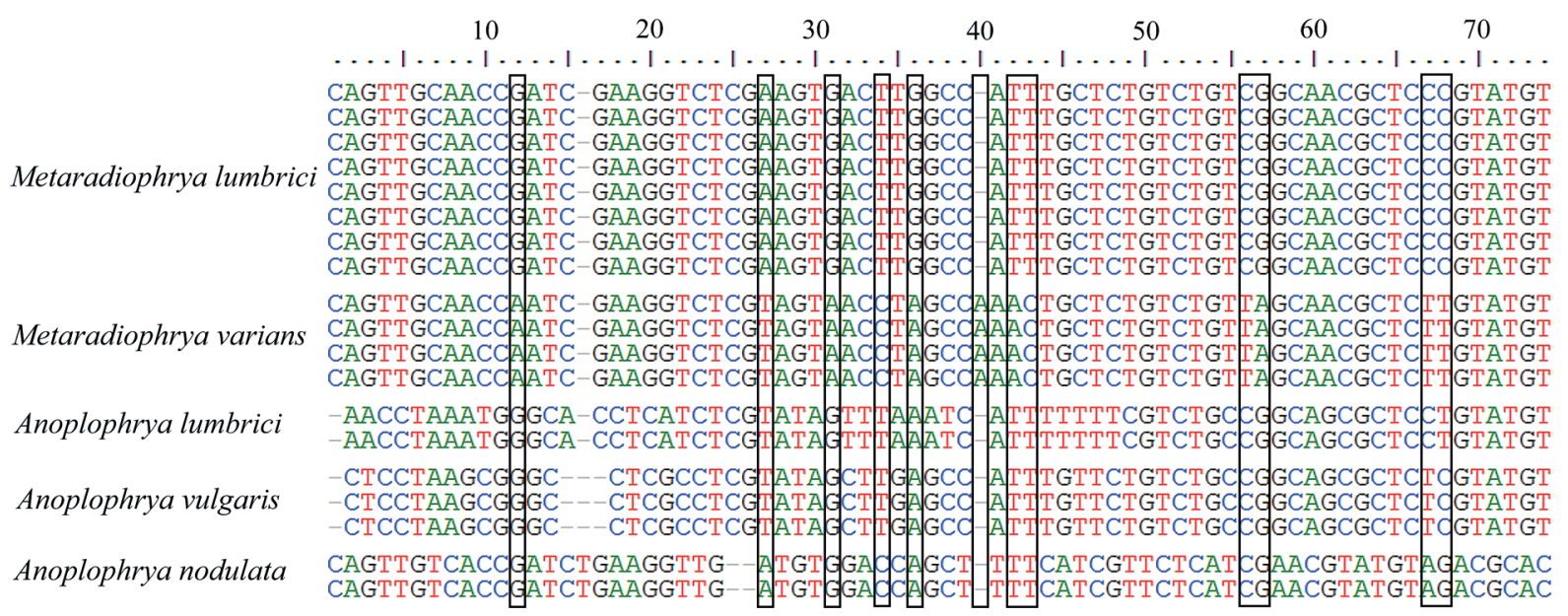

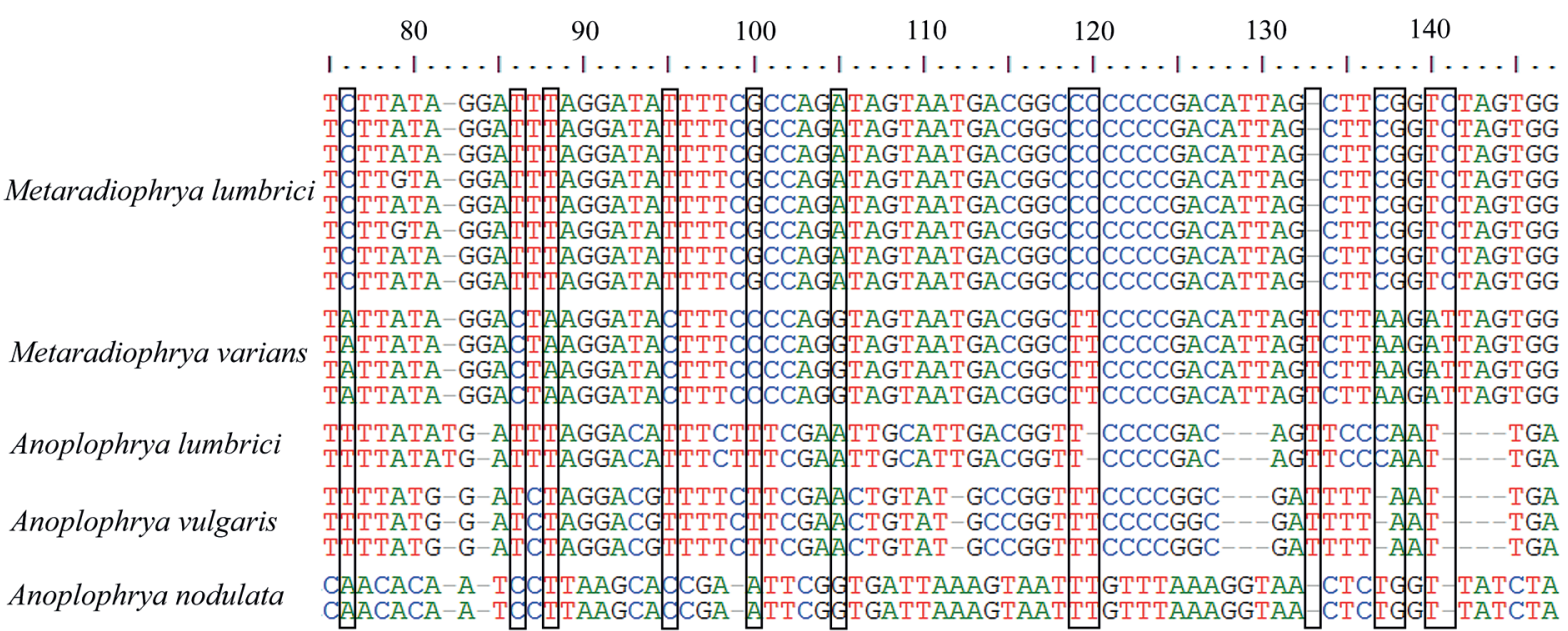

Fig. 16. Alignment of variable positions of the $18 \mathrm{~S}$ rRNA gene of five astome ciliates isolated from the lumbricid earthworms. Boxes mark 25 nucleotide positions in which M. lumbrici (Dujardin, 1841) differs from M. varians (de Puytorac, 1954). The comparison with three outgroup species of Anoplophrya Stein, 1860 indicates that 19 out of the 25 variable nucleotide positions of $M$. lumrici are either plesiomorphies or possibly homoplasies. 
Table 5. Average between group evolutionary distances (below diagonal) and their standard errors (above diagonal) estimated with the maximum composite likelihood method.

\begin{tabular}{lccccc}
\hline & $\mathbf{1 .}$ & $\mathbf{2 .}$ & $\mathbf{3 .}$ & $\mathbf{4 .}$ & $\mathbf{5 .}$ \\
\hline 1. Metaradiophrya lumbrici & - & 0.0032 & 0.0058 & 0.0056 & 0.0096 \\
2. Metaradiophrya varians & 0.0138 & - & 0.0066 & 0.0062 & 0.0098 \\
3. Anoplophrya lumbrici & 0.0318 & 0.0380 & - & 0.0037 & 0.0120 \\
4. Anoplophrya vulgaris & 0.0304 & 0.0352 & 0.0168 & - & 0.0113 \\
5. Anoplophrya nodulata & 0.0608 & 0.0627 & 0.0752 & 0.0717 & - \\
\hline
\end{tabular}

Based on the integrative taxonomic approach, two species of Metaradiophrya were isolated from the lumbricid earthworms during the course of the present study: M. lumbrici and M. varians. The former species was detected exclusively in the group of anecic earthworms. However, Heidenreich (1935) also reported M. lumbrici from an ecologically different group of earthworms, namely, from the epigeic L. rubellus Hoffmeister, 1843 and E. fetida (for problems with ciliate identity, see below). Apart from L. terrestris, Lom (1961) recorded M. lumbrici also in Dendrobaena illyrica (Cognetti, 1906). De Puytorac (1972) extended the host spectrum of M. lumbrici by a further species from the family Lumbricidae, namely, L. herculeus (Savigny, 1826). On the other hand, Williams (1942) did not report M. lumbrici from the gastrointestinal tract of L. terrestris at all but from "Eisenia foetidus". Metaradiophrya varians has so far been reported exclusively from E. fetida (de Pyutorac 1954, 1972; Lom 1961; Paisán et al. 2009; present study). As evidenced by molecular data, we have never recorded M. lumbrici in E. fetida. All sequences of Metaradiophrya from this epigeic earthworm were $100 \%$ identical. According to morphometric data, they belong to M. varians which has a lower number of fibres associated with the ventral side of the longer arm of the hook than $M$. lumbrici (see above and de Pyutorac 1954, 1972; Lom 1961; Paisán et al. 2009). Therefore, we assume that Heidenreich (1935) and Williams (1942) misidentified M. varians as M. lumbrici.

According to the compendium of de Puytorac (1972), eight further species of Metaradiophrya were reported from earthworms of the family Lumbricidae: (1) M. asymmetrica (Beers, 1938) from "Eisenia lönnbergi(Michlsn, 1844)"'[=Eisenoideslonnbergi(Michaelsen, 1894)];(2) M. bifulta (dePuytorac, 1954) from Helodrilus schneideri Michaelsen, 1900; (3) M. chlorotica (Williams, 1942) from Allolobophora chlorotica (Savigny, 1826); (4) M. falcifera (Stein, 1861) from L. rubellus, Nicodrilus caliginosus [= Aporrectodea caliginosa (Savigny, 1826)] and Octolasion lacteum (Örley, 1881); (5) M. gardneri (Rees, 1961) from Eisenia fetida; (6) M. gigas de Puytorac, 1954 from Aporrectodea savignyi [= Scherotheca savignyi (Guerne \& Horst, 1893)]; (7) M. heidenreichi (de Puytorac, 1954) from Helodrilus schneideri; and (8) M. hovassei (de Puytorac, 1954) from Allolobophora chlorotica and Eisenia rosea (Savigny, 1826).

In the course of the present study, three species of Anoplophrya were reported from the lumbricid earthworms: A. lumbrici, A. vulgaris and A. nodulata. We detected $A$. lumbrici exclusively in the anecic L. terrestris. Similarly, Heidenreich (1935) and de Puytorac (1972) mentioned L. terrestris as the host of A. lumbrici. Lom (1961), in addition, reported A. lumbrici from the epigeic earthworms L. rubellus and D. subrubicunda [= Dendrodrilus rubidus subrubicundus (Eisen, 1874)] in which, however, exemplars of $A$. lumbrici exhibited conspicuous morphological differences. This indicates that they might represent different species of Anoplophrya. Heidenreich (1935) considered A. marylandensis to be a junior synonym of $A$. lumbrici, which is also indicated by the present phylogenetic analyses (Figs 14-15). Sequences of $A$. marylandensis and A. lumbrici, originating from the same host organisms (L. terrestris), clustered together in our phylogenetic analyses and had a 99.3\% identity. However, we cannot exclude that the difference of $0.7 \%$ in the $18 \mathrm{~S}$ rRNA gene is sufficient to separate $A$. marylandensis 
OBERT T. \& VĎAČNÝ P., Morphology and phylogeny of five astome ciliates

Table 6. Log likelihoods and $p$-values of the AU, WSH and WKH tests to compare different topological scenarios. Significant differences $(p$-value $<0.05)$ between the best unconstrained and constrained topologies in bold face.

\begin{tabular}{|c|c|c|c|c|c|}
\hline Topology & $-\ln \mathbf{L}^{\mathbf{a}}$ & $\Delta(-\ln \mathbf{L})^{b}$ & $\mathbf{A U}$ & WSH & WKH \\
\hline Best scoring maximum likelihood tree (unconstrained) & 5056.68 & - & 0.860 & 0.987 & 0.812 \\
\hline Monophyly of $M$. lumbrici and $M$. varians & 5059.33 & 2.6 & 0.165 & 0.440 & 0.188 \\
\hline $\begin{array}{l}\text { Monophyly of } M \text {. lumbrici, } M \text {. varians and } \\
\text { Metaradiophrya sp. HQ446279 }\end{array}$ & 5199.22 & 142.5 & $6 e-37$ & 0.000 & 0.000 \\
\hline Monophyly of the genus Metaracoelophrya & 5078.25 & 21.6 & 0.002 & 0.016 & 0.010 \\
\hline
\end{tabular}

from A. lumbrici. For instance, two species of Paraclausilocola are morphologically clearly distinct but are only $0.3 \%$ divergent in their $18 \mathrm{~S}$ rRNA gene sequences. Therefore, at the present state of knowledge, it might be premature to synonymize $A$. marylandensis with $A$. lumbrici. Conklin (1930) discovered A. marylandensis in L. terrestris and Helodrilus caliginosus [= Aporrectodea caliginosa (Savigny, 1826)]. Lom (1961) considered A. marylandensis as a valid species and recorded it rarely in Allolobophora longa [= Aporrectodea longa (Ude, 1885)] and Dendrobaena octaedra (Savigny, 1826). However, Lom (1961) did not list these two species in his comprehensive table but provided there two completely different earthworm species, Octolasium lacteum [= Octolasion lacteum $]$ and Allolobophora caliginosa [= Aporrectodea caliginosa]. Due to the conflicts between text and tables, it is not possible to state where Lom (1961) detected A. marylandensis.

Heidenreich (1935) also considered A. alluri Cépède, 1910, A. lloydii Ghosh, 1918 and A. striata (Dujardin, 1841) as junior synonyms of $A$. lumbrici. In addition, he also found $A$. striata as synonyms of A. alluri and A. nodulata. According to Lom (1961), A. alluri is also a junior synonym of A. nodulata. Whether the two latter species are conspecific and also identical with A. simplex Nana et al., 2018 is difficult to decide at the present state of knowledge. However, synonymization of $A$. alluri and $A$. nodulata with $A$. lumbrici is not justified in the light of both morphological (two rows of contractile vacuoles vs a single row of vacuoles) and molecular (Figs 14-15) data. Cépède (1910) discovered Anoplophrya alluri in Allurus tetraedrus [= Eiseniella tetraedra (Savigny, 1826)], but he provided a much wider host spectrum for A. striata: L. rubellus, L. terrestris, L. variegatus [= Lumbriculus variegatus (Müller, 1774)], E. foetida and Al. chlorotica. According to Ghosh (1918), A. lloydii originated from Pheretima posthuma [= Perichaeta posthuma Vaillant, 1868] which, however, does not belong to the family Lumbricidae but to the Megascolecidae. Anoplophrya simplex was isolated from Alma emini (Michaelsen, 1892) which belongs to the Glossoscolecidae (Nana et al. 2018). Therefore, conspecificity of A. alluri, A. lloydii and A. simplex is unlikely, although all three species display two rows of contractile vacuoles.

We detected A. vulgaris exclusively from the epigeic earthworms E. fetida and D. veneta. Ciliate 18S rRNA gene sequences obtained from both hosts were identical. Similarly, de Puytorac (1954, 1972), Lom (1961) and Paisán et al. (2009) reported A. vulgaris from epigeic earthworms. The third detected species of Anoplophrya in the present study was identified as A. nodulata. Heidenreich (1935) considered it incorrectly as a junior synonym of $A$. lumbrici (see above). Dujardin (1841) did not specify the host organism in which he discovered $A$. nodulata. We have detected it exclusively in a single endogeic species, $O$. tyrtaeum. Lom (1961) frequently recorded A. nodulata in E. tetraedra and rarely in A. caliginosa. Because of quite different host species, the conspecificity of our and Lom's (1961) populations is questionable and needs to be tested by molecular data. 
According to the compendium of de Puytorac (1972), seven further species of Anoplophrya were reported from earthworms of the family Lumbricidae: (1) Anoplophrya commune de Puytorac, 1954 from Allolobophora savignyi [= Scherotheca savignyi]; (2) Anoplophrya enigmatica (authorship not provided by de Puytorac 1972) from Dendrobaena subrubicunda [= Dendrodrilus rubidus subrubicundus]; (3) Anoplophrya oblonga de Puytorac, 1954 from L. herculeus and L. terrestris; (4) Anoplophrya problematica (authorship not provided by de Puytorac 1972) from Dendrobaena illyrica; (5) Anoplophrya singularis de Puytorac, 1954 from L. festivus (Savigny, 1826); (6) Anoplophrya suspicata (authorship not provided by de Puytorac 1972) from L. castaneus (Savigny, 1826); and (7) Anoplophrya tchadovi de Puytorac, 1958 from "Eiseniella ohridana Cern" [= E. tetraedra var. ochridana Černosvitov, 1931].

The present phylogenetic analyses did not support monophylies of the genera Metaracoelophrya, Metaradiophrya and Anoplophrya (Figs 14-15). Monophyly of Metaracoelophrya was also firmly refuted by all statistical tree topology tests (Table 6). To solve this taxonomic problem, details on morphology of the three species of Metaracoelophrya are needed. Likewise, monophyly of M. lumbrici, M. varians and Metaradiophrya sp. HQ446279 was consistently rejected, although monophyly of M. lumbrici and M. varians could not be excluded by any statistical test (Table 6). However, examination of the dissertation thesis of Fokam (2012) revealed that Metaradiophrya sp. HQ446279 (= "Metaradiophrya simplex" in his thesis) is obviously not a Metaradiophrya, since it does not possess a fibrillar hook composed of two unequally long arms. Finally, polyphyly of the genus Anoplophrya is caused in that A. nodulata clusters far away from the A. lumbrici + A. marylandensis $+A$. vulgaris clade. As mentioned above, the genetic divergence of $A$. nodulata and the two other species of Anoplophrya is comparatively big (0.0717-0.0752) and even greater than from the two species of Metaradiophrya (0.0608-0.0627). Since A. nodulata is distinguished from the two other species of Anoplophrya by the contractile vacuole pattern (two rows vs one row) and by the ecological group of host earthworms (endogeic vs anecic or epigeic), it should be transferred to a distinct genus. However, due to the lack of detailed morphological data on $A$. nodulata, we prefer not to establish a new genus in the present study.

It is important to emphasize that all literature data on occurrence of astome ciliates in the digestive tract of oligochaetes from the family Lumbricidae are problematic due to taxonomic difficulties and lack of molecular data. Our integrative approach revealed that reliable identification of astome ciliates also requires molecular data. Moreover, our phylogenetic analyses also suggest that astome ciliates might be associated with certain ecological and systematic groups of their host organisms. Therefore, occurrence of individual astome species in ecologically different and phylogenetically distant earthworms seems to be unlikely and needs to be corroborated by molecular data.

\section{Acknowledgements}

We are grateful to Jaroslav Bella (Botanic Garden of Comenius University), Markéta Derdáková, Miroslav Obert, Jana Pazderová, Danica Smoláriková and Vladimír Vd’ačný for enabling us to sample in their gardens. This work was supported by the Slovak Research and Development Agency under the contract No. APVV-15-0147 and by the Grant Agency of the Ministry of Education, Science, Research and Sport of the Slovak Republic and Slovak Academy of Sciences under the Grants VEGA 1/0041/17 and VEGA 1/0114/16. 


\section{References}

Abraham J.S., Sripoorna S., Maurya S., Makhija S., Gupta R. \& Toteja R. 2019. Techniques and tools for species identification in ciliates: a review. International Journal of Systematic and Evolutionary Microbiology 69: 877-894. https://doi.org/10.1099/ijsem.0.003176

Affa'a F.-M., Hickey D.A., Strüder-Kypke M. \& Lynn D.H. 2004. Phylogenetic position of species in the genera Anoplophrya, Plagiotoma, and Nyctotheroides (phylum Ciliophora), endosymbiotic ciliates of annelids and anurans. Journal of Eukaryotic Microbiology 51: 301-306. https://doi.org/10.1111/j.1550-7408.2004.tb00570.x

Beers C.D. 1938. Structure and division in the astomatous ciliate Metaradiophrya asymmetrica n. sp. Journal of the Elisha Mitchell Scientific Society 54: 111-125.

Bush M. 1933. The morphology of the ciliate Haptophrya michiganensis Woodhead and its relation to other members of the Astomatea. Transactions of the American Microscopic Society 52: 223-232. https://doi.org/10.2307/3222257

Bush M. 1934. The morphology of Haptophrya michiganensis Woodhead, an astomatous ciliate from the intestinal tract of Hemidactylium scutatum (Schlegel). University of California Publications in Zoology 39: 251-275.

Cépède C. 1910. Recherches sur les infusoires astomes. Anatomie, biologie, ethologie parasitaire, systématique. Archives de Zoologie expérimentale et générale 5: 341-609.

Conklin C. 1930. Anoplophrya marylandensis n. sp., a ciliate from the intestine of earthworms of the family Lumbricidæ. Biological Bulletin 58: 176-181. https://doi.org/10.2307/1536863

Corliss J.O., de Puytorac P. \& Lom J. 1965. Resolution of persistent taxonomic and nomenclatural problems involving ciliate protozoa assignable to the astome family Haptophryidae Cepede, 1923. Journal of Protozoology 12: 265-273. https://doi.org/10.1111/j.1550-7408.1965.tb01849.x

Darriba D., Taboada G.L., Doallo R. \& Posada D. 2012. jModelTest 2: more models, new heuristics and parallel computing. Nature Methods 9: 772. https://doi.org/10.1038/nmeth.2109

de Puytorac P. 1954. Contribution à l'étude cytologique et taxonomique les infusoires astomes. Annales des Sciences naturalles, Zoologie et Biologie animale 11: 85-270.

de Puytorac P. 1957. L'infraciliature de quelques ciliés Haptophryidae. Caparaison avec celle de certains thigmotriches. Comptes Rendus hebdomadaires Séances de l'Académie des Sciences 244: 1962-1965.

de Puytorac P. 1963. Contribution à l'étude des ciliés astomes Haptophryidae Cépède, 1903 (cytologie, ultrastructure, taxinomie). Annales des Sciences naturelles, Zoologie et Biologie animale 5: 173-210.

de Puytorac P. 1969. Les Ciliés Astomes Hoplitophryidae. I. Description de nouvelles espèces. Protistologica 5: 255-268.

de Puytorac P. 1972. Les Ciliés Astomes Hoplitophryidae. II. Révision de la systématique de ce groupe. Protistologica 8: 5-42.

de Puytorac P. \& Schrével J. 1965. Nouvelles espèces de Ciliés Astomes endoparasites d'Annélides Polychètes. Annales de la Faculte des Sciences de l'Universite de Clermont 28: 85-99.

Dujardin F. 1841. Histoire naturelle des zoophytes. Infusoires, comprenant la physiologie et la classification de ces animaux, et la maniére de les étudier a l'aide du microscope. Librairie Encyclopédique de Roret, Paris. 
Foissner W. 2014. An update of 'basic light and scanning electron microscopic methods for taxonomic studies of ciliated protozoa'. International Journal of Systematic and Evolutionary Microbiology 64: 271-292. https://doi.org/10.1099/ijs.0.057893-0

Fokam Z. 2012. Etude morphologique et phylogénie des Ciliés Astomes endocommensaux d'Oligochètes terricoles de la région de Yaoundé et ses environs. $\mathrm{PhD}$ thesis, Université de Yaoundé I, Cameroon.

Fokam Z., Nhassam P., Boutin C. \& Togouet S.H.Z. 2008. Trois espèces nouvelles de Coelophrya, Ciliés Astomes endocommensaux d'Alma nilotica (oligochète terricole) du Cameroun. Bulletin de la Société d'Histoire naturelle de Toulouse 144: 27-33.

Fokam Z., Ngassam P., Strüder-Kypke M.C. \& Lynn D.H. 2011. Genetic diversity and phylogenetic position of the subclass Astomatia (Ciliophora) based on a sampling of six genera from West African oligochaetes (Glossoscolecidae, Megascolecidae), including description of the new genus Paraclausilocola n. gen. European Journal of Protistology 47: 161-171.

https://doi.org/10.1016/j.ejop.2011.02.002

Fokam Z., Nana P.A., Moche K., Bricheux G., Bouchard P., Ngassam P. \& Sime-Ngando T. 2015. Influence of soil physicochemical parameters on the abundance of Paracoelophrya polymorphus (Ciliophora: Radiophryidae) commensal of earthworms (Annelida: Glossoscolecidae) collected in Bambui (North-West Cameroon). Journal of Biodiversity and Environmental Sciences 6: 376-389.

Fokam Z., Nana P.A., Bricheux G., Vigues B., Bouchard P., Ngassam P. \& Sime-Ngando T. 2016. Correlation between some environmental variables and abundance of Almophrya mediovacuolata (Ciliophora: Anoplophryidae) endocommensal ciliate of an anecic earthworms (Oligochaeta: Annelida) in Bambui (North-West Cameroon). International Journal of Biological and Chemical Sciences 10: 1983-1997. https://doi.org/10.4314/ijbcs.v10i5.4

Ghosh E. 1918. Studies on Infusoria. Records of the Indian Museum (Calcutta) 15: 129-134.

Gower J.C. 1971. A general coefficient of similarity and some of its properties. Biometrics 27: 857-871. https://doi.org/10.2307/2528823

Guindon S., Dufayard J.F., Lefort V., Anisimova M., Hordijk W. \& Gascuel O. 2010. New algorithms and methods to estimate maximum-likelihood phylogenies: assessing the performance of PhyML 3.0. Systematic Biology 59: 307-321. https://doi.org/10.1093/sysbio/syq010

Hall T.A. 1999. BioEdit: a user-friendly biological sequence alignment editor and analysis program for Windows 95/98/NT. Nucleic Acids Symposium Series 41: 95-98.

Heidenreich E. 1935. Untersuchungen an parasitischen Ciliaten aus Anneliden. Teil I: Systematik. Archiv für Protistenkunde 84: 315-392.

Hunter J.D. 2007. Matplotlib: a 2D graphics environment. Computing in Science and Engineering 9: 90-95.

Irwin N.A.T. \& Lynn D.H. 2015. Molecular phylogeny of mobilid and sessilid ciliates symbiotic in eastern pacific limpets (Mollusca: Patellogastropoda). Journal of Eukaryotic Microbiology 62: 543-552. https://doi.org/10.1111/jeu.12208

Irwin N.A.T., Sabetrasekh M. \& Lynn D.H. 2017. Diversification and phylogenetics of mobilid peritrichs (Ciliophora) with description of Urceolaria parakorschelti sp. nov. Protist 168: 481-493. https://doi.org/10.1016/j.protis.2017.07.003

Kay M.W. 1942. A new astomatous ciliate from the newt, Eurycea bislineata (Green). American Midland Naturalist Journal 27: 422-427. 
OBERT T. \& VĎAČNÝ P., Morphology and phylogeny of five astome ciliates

Kijenskij G. 1926. Nálevníci zažívací roury některých Oligochaetů pražského okolí (Morfologie. Nepohlavní množení. Systematika). Věstník Královské České Společnosti Nauk, Třída MatematickoPř́rodovédecká year 1925 (I): 1-32.

Kumar S., Stecher G., Li M., Knyaz C. \& Tamura K. 2018. MEGA X: Molecular Evolutionary Genetics Analysis across computing platforms. Molecular Biology and Evolution 35: 1547-1549.

https://doi.org/10.1093/molbev/msy096

Lom J. 1959. Beiträge zur Kenntnis der parasitischen Ciliaten aus Evertebraten. IV Neue Ciliaten aus der Familie Haptophryidae Cépède 1923, nebst einigen Bemerkungen zum heutigen Stand dieser Gruppe. Archiv für Protistenkunde 104: 133-154.

Lom J. 1961. Some remarks on the morphology and taxonomy of astomatous ciliates from earthworms. Acta Societatis Zoologicae Bohemoslovenicae 25: 167-180.

Lynn D.H. 2008. The Ciliated Protozoa. Characterization, Classification and Guide to the Literature. $3^{\text {rd }}$ ed. Springer, Dordrecht.

Maupas E. 1879. Sur l'Haptophyra gigantea opaline nouvelle de l'intestine des batraciens anoures d'Algérie. Comptes Rendus hebdomadaires Séances de l'Académie des Sciences 88: 921-923.

McAllister C.T. \& Trauth S.E. 1996. Ultrastructure of Cepedietta virginiensis (Protista: Haptophryidae) from the gall bladder of the pickerel frog, Rana palustris, in Arkansas. Proceedings of the Arkansas Academy of Science 50: 133-136.

McAllister C.T., Upton S.J. \& Trauth S.E. 1993. Endoparasites of western slimy salamanders, Plethodon albagula (Caudata: Plethodontidae), from Arkansas. Journal of the Helminthological Society of Washington 60: 124-126.

McKinney W. 2010. Data structures for statistical computing in Python. In: van der Walt S. \& Millman J. (eds) Proceedings of the $9^{\text {th }}$ Python in Science Conference: 51-56. Austin, Texas.

Medlin L., Elwood H.J., Stickel S. \& Sogin M.L. 1988. The characterization of enzymatically amplified eukaryotic 16S-like rRNA-coding regions. Gene 71: 491-499.

Miller M.A., Pfeiffer W. \& Schwartz T. 2010. Creating the CIPRES Science Gateway for inference of large phylogenetic trees. In: Proceedings of the Gateway Computing Environments Workshop (GCE): 1-8. Piscataway, N.J., New Orleans, Louisiana.

Nana P.A., Fokam Z., Viguès B., Bricheux G., Aghaindum G.A., Ngassam P., Nola M. \& Sime-Ngando T. 2018. Morphology and infraciliature of two new earthworm ciliates, Hoplitophrya polymorphus sp. nov. and Anoplophrya simplex sp. nov. (Ciliophora: Oligohymenophorea: Astomatia). Zootaxa 4392: 169178. http://dx.doi.org/10.11646/zootaxa.4392.1.9

Ngassam P. 1983. Trois espèces nouvelles de ciliés Astomes des genres: Almophrya de Puytorac et Dragesco, 1968, Maupasella Cépède, 1910, Njinella nov. genre, endocommensaux d'Annélides oligochètes de la région de Yaoundé. Protistologica 19: 131-135.

Ngassam P., Fokam Z., Gangoué P.J. \& Motchebe N.G.M. 1998. Complément à la connaissance de deux ciliés Astomes endocommensaux d'Oligochètes terricoles de la région de Yaoundé. Cameroun Journal of Biological and Biochemical Sciences 8: 17-30.

Oliphant T.E. 2015. Guide to NumPy. $2^{\text {nd }}$ ed. Continuum Press, Austin, Texas.

Paisán L., Alonso P., Anadón R. \& Alvarez S. 2009. Descripción y primera mención en España de cuatro especies de ciliados endobiontes de Eisenia fetida (Savigny, 1826) (Annelida, Oligochaeta, Lumbricidae). Boletín de la Real Sociedad Española de Historia Natural, Sección Biológica 103:37-47. 
Pedregosa F., Varoquaux G., Gramfort A., Michel V., Thirion B., Grisel O., Blondel M., Pettenhofer P., Weiss R., Dubourg V., Vanderplas J., Passos A., Cournaupeau D., Brucher M., Perrot M. \& Duchesnay É. 2011. Scikit-learn: Machine Learning in Python. Journal of Machine Learning Research 12: 2825-2830.

Pižl V. 2002. Žížaly České republiky. Sbornik přirodovědného klubuv Uherskom Hradišti Supplementum 9: $1-154$.

Rataj M. \& Vd’ačný P. 2018. Dawn of astome ciliates in light of morphology and time-calibrated phylogeny of Haptophrya planariarum, an obligate endosymbiont of freshwater turbellarians. European Journal of Protistology 64: 54-71. https://doi.org/10.1016/j.ejop.2018.03.004

Rataj M. \& Vd'ačný P. 2019. Living morphology and molecular phylogeny of oligohymenophorean ciliates associated with freshwater turbellarians. Diseases of Aquatic Organisms 134: 147-166.

https://doi.org/10.3354/dao03366

Ronquist F., Teslenko M., van der Mark P., Ayres D.L., Darling A., Höhna S., Larget B., Liu L., Suchard M.A. \& Huelsenbeck J.P. 2012. MrBayes 3.2: efficient Bayesian phylogenetic inference and model choice across a large model space. Systematic Biology 61: 539-542.

https://doi.org/10.1093/sysbio/sys029

Rossolimo L. 1926a. Parasitische Infusorien aus dem Baikalsee. Archiv für Protistenkunde 54: 468-510.

Rossolimo L. 1926b. Über einige neue und wenig bekannte Infusoria-Astomata aus den Anneliden des russischen Nordens. Zoologischer Anzeiger 68: 52-57.

Sauvadet A.L., Lynn D.H., Roussel E.G., Le Panse S., Bigeard E., Schrével J. \& Guillou L. 2017. Redescription and phylogenetic analyses of Durchoniella spp. (Ciliophora, Astomatida) associated with the polychaete Cirriformia tentaculata (Montagu, 1808). European Journal of Protistology 61: 265-277. https://doi.org/10.1016/j.ejop.2017.06.007

Schneider C.A., Rasband W.S. \& Eliceiri K.W. 2012. NIH Image to ImageJ: 25 years of image analysis. Nature Methods 9: 671-675. https://doi.org/10.1038/nmeth.2089

Schultze M.S. 1851. Beiträge zur Naturgeschichte der Turbellarien. C.A. Koch's Verlagshandlung, Greifswald.

Sela I., Ashkenazy H., Katoh K. \& Pupko T. 2015. GUIDANCE2: accurate detection of unreliable alignment regions accounting for the uncertainty of multiple parameters. Nucleic Acids Research 43: W7-W14. https://doi.org/10.1093/nar/gkv318

Shimodaira H. 2002. An approximately unbiased test of phylogenetic tree selection. Systematic Biology 51: 492-508. https://doi.org/10.1080/10635150290069913

Shimodaira H. 2008. Testing regions with non-smooth boundaries via multiscale bootstrap. Journal of Statistical Planning and Inference 138: 1227-1241. https://doi.org/10.1016/j.jspi.2007.04.001

Shimodaira H. \& Hasegawa M. 2001. CONSEL: for assessing the confidence of phylogenetic tree selection. Bioinformatics 17: 1246-1247. https://doi.org/10.1093/bioinformatics/17.12.1246

Sikora J. 1963. Study on the parasitic ciliate Steinella uncinata (Schultze). Acta Protozoologica 1: 1320 .

Swofford D.L. 2003. PAUP*. Phylogenetic Analysis Using Parsimony (*And Other Methods). Version 4.0b 10. Sinauer Associates, Sunderland.

Tamura K. \& Kumar S. 2002. Evolutionary distance estimation under heterogeneous substitution pattern among lineages. Molecular Biology and Evolution 19: 1727-1736.

https://doi.org/10.1093/oxfordjournals.molbev.a003995 
Vd’ačný P. 2018. Evolutionary associations of endosymbiotic ciliates shed light on the timing of the marsupial-placental split. Molecular Biology and Evolution 35: 1757-1769.

https://doi.org/10.1093/molbev/msy071

Vd’ačný P., Érseková E., Šoltys K., Budiš J., Pecina L. \& Rurik I. 2018. Co-existence of multiple bacterivorous clevelandellid ciliate species in hindgut of wood-feeding cockroaches in light of their prokaryotic consortium. Scientific Reports 8: 17749. https://doi.org/10.1038/s41598-018-36245-y

Vd'ačný P., Rajter L., Stoeck T. \& Foissner W. 2019. A proposed timescale for the evolution of armophorean ciliates: clevelandellids diversify more rapidly than metopids. Journal of Eukaryotic Microbiology 66: 167-181. https://doi.org/10.1111/jeu.12641

von Siebold C.T. 1839. Beiträge zur Naturgeschichte der wirbellosen Thiere. Ueber Medusa, Cyclops, Loligo, Gregarina und Xenos. Neueste Schriften der Naturforschenden Gesellschaft in Danzig, Vol 3. Fr. Sam. Gerhard, Danzig.

Williams G.W. 1942. Observations on several species of Metaradiophrya (Protozoa, Ciliata). Journal of Morphology 70: 545-589.

Manuscript received: 13 May 2019

Manuscript accepted: 15 July 2019

Published on: 1 October 2019

Topic editor: Rudy Jocqué

Desk editor: Eva-Maria Levermann

Printed versions of all papers are also deposited in the libraries of the institutes that are members of the EJT consortium: Muséum national d'Histoire naturelle, Paris, France; Meise Botanic Garden, Belgium; Royal Museum for Central Africa, Tervuren, Belgium; Royal Belgian Institute of Natural Sciences, Brussels, Belgium; Natural History Museum of Denmark, Copenhagen, Denmark; Naturalis Biodiversity Center, Leiden, the Netherlands; Museo Nacional de Ciencias Naturales-CSIC, Madrid, Spain; Real Jardín Botánico de Madrid CSIC, Spain; Zoological Research Museum Alexander Koenig, Bonn, Germany; National Museum, Prague, Czech Republic. 